ARTICLE

DOI: $10.1057 /$ s41599-017-0033-0

\title{
Inter-state relations and state capacity: the rise and fall of Chinese foreign direct investment in the Philippines
}

\author{
Alvin Camba ${ }^{1}$
}

\begin{abstract}
What drives Chinese foreign direct investment (FDI)? While the literature in organizational and business studies has established a strong positive association between Chinese foreign direct investments (FDI) and weak institutions in the developing world, these works have generally underexamined how inter-state relations between China and the host country impact Chinese FDI. This paper examines Chinese FDI in the Philippines during the Arroyo (2001-2010), Aquino (2010-2016), and Duterte (2016-) presidencies. Since sufficient variation across these administrations can be found in the volatility of Chinese FDI, the different levels of state capacity, and the vacillation of inter-state relations with China, the Philippine case sets up an ideal within-case comparison to analyze how inter-state relations figure in the relationship of Chinese FDI and weak institutions while holding other potentially confounding factors constant. This article argues that the rise and fall of Chinese FDI depend not only on the conflictual or cooperative relations between China and the host country, but also on the strength or weakness of various types of state capacity. State capacity mediates the impact of inter-state relations on the three kinds of Chinese FDI: (1) state investments; (2) private investments; and (3) illicit capital. Specifically, conflictual relations can constrain state investments and encourage the flow of illicit capital. Conversely, cooperative relations can encourage state investments and hinder the flow of illicit capital. Private investments depend on the legal-administrative and fiscal capacity of the state while illicit capital can be constrained by the host country's coercive capacity. Infrastructural power can affect the realization of state and private investments. In showing the responses of these three kinds of Chinese FDI to inter-state relations as well as the strength or weakness of various types of state capacity in the host country, the paper modifies the assumption in the literature that weak institutions draw in high-levels of Chinese FDI. Supported by in-depth key-informant interviews with Philippine government officials, politicians, and Chinese investors, this finding demonstrates the protean nature of Chinese FDI: it is able to adapt to different political conditions and historical circumstances.
\end{abstract}

\footnotetext{
1John Hopkins University, Baltimore, MD 21218, USA. Correspondence and requests for materials should be addressed to A.C. (email: acamba1@jhu.edu)
} 


\section{Introduction}

ecent literature in organizational and business studies have established a strong positive association between Chinese foreign direct investments (FDI) and weak institutions in the developing world (Cheung and Qian, 2009, Duanmu, 2012). For instance, Kang and Jiang (2012, p 49) estimate the locational preference of Chinese multinational corporations using conventional economic indicators, the degree of political similarity, and the cultural distance between the People's Republic of China (PRC) and the host country. Similarly, Kolstad and Wiig (2012, p 32) analyze similar economic variables, but include geographic distance and political institutions. ${ }^{1}$ However, all of these works overlook China's increasingly assertive role in territorial disputes, which can lead to potential conflict between and among states. For instance, in the Senkaku Islands, a group of small islets that have been in Japanese suzerainty since 1972, China announced that it would take an aggressive stance in 1999. In China's South-Western region, the Sino-Indian border dispute has recently been rekindled over the Arunachal Pradesh, breaking the bilateral truce established in 1997. Most prominently, in the South China Sea, amid a territorial dispute with Taiwan or Republic of China, Indonesia, Malaysia, Brunei, Vietnam, and the Philippines, the PRC has constructed maritime infrastructure and disregarded international law. ${ }^{2}$

As an alternative investor and the biggest contributor to the decline of global inequality until the early 2000s (Hung 2015, p 102), China's rise has largely been positive for the developing world, yet its increased economic power has been accompanied by an aggressive stance on territorial claims. If territorial disputes alter the PRC's inter-state relations, or the political relationship with the host country, how do these changes affect Chinese FDI? In other words, what drives Chinese FDI? While quantitative studies on Chinese FDI do not take inter-state relations into account, qualitative works have generally focused on China's development impact on host countries. ${ }^{3}$ To bring inter-state relations into the study of Chinese FDI and weak institutions, I conduct a within-case comparison of Chinese FDI in the Philippines during the administrations of Gloria Macapagal Arroyo (2001-2010), Benigno Aquino III (2010-2016), and Rodrigo Duterte (2016-). As these three administrations feature sufficient variation in the volatility of Chinese FDI, the strength or weakness of various types of state capacity, and the changes in interstate relations, the Philippine case allows for the comparison of the different configuration of causes and outcomes while holding other potentially confounding factors constant.

First, the amount of Chinese FDI in the Philippines fluctuated from one administration to another. Under Arroyo, the Philippines became the first country in Southeast Asia to welcome Chinese overseas developmental aid (ODA) and FDI. Despite initial promise, Arroyo eventually canceled almost all the major Chinese projects near the end of her term. During the Aquino administration, Chinese state investments dissipated but smaller private investments increased despite tensions in the South China Sea. More recently, President Duterte reached an investment agreement with the PRC that earmarked for at least US $\$ 24$ billion (Ranada, 2016). Second, despite the numerous corruption scandals and rent-seeking bureaucrats that plagued Arroyo, ironically, it was Aquino who benefitted from key economic reforms enacted during her administration that led to improvements in state capacity. ${ }^{4}$ Similarly, Duterte also "inherited" state capacity that have their origins in the fiscal and legal-administrative reforms of Aquino's administration. And lastly, inter-state relations between the Philippines and China vacillated from Arroyo to Duterte. During the Arroyo presidency, the South China Sea dispute was shelved in favor of joint maritime cooperation and exploration while Aquino experienced increased but contained tensions with China as a result of territorial disputes over the South China Sea, culminating in an international case at The Hague and numerous maritime standoffs. As for Duterte, he opted to quell conflict and instead forge strong diplomatic relations with China.

I argue that the rise and fall of Chinese FDI depend not only on the conflictual or cooperative relations between China and the host country, but also on strength or weakness of various types of state capacity. State capacity, or the state's organizational apparatus, mediates the impact of interstate relations and the three kinds of Chinese FDI: (1) state investments, funded by the sending country often through overseas developmental aid (ODA), that usually go to infrastructures and megaprojects; (2) private investments, or small and medium enterprises typically in manufacturing and services; and (3) illicit capital funneled by private companies to local allies in the warring state, usually found in the extractive sector. Cooperative relations can encourage state investments and hinder the flow of illicit capital. Conversely, conflictual relations can constrain state investments and encourage the flow of illicit capital. The various types of state capacity impact different kinds of FDI. Private investments and illicit capital depend on the legal-administrative and fiscal capacity of the state while illicit capital can be constrained by the host country's coercive capacity. Infrastructural power, as a type of state capacity concerned with state-society relations, can affect the realization of state and private investments.

Empirically, when cooperative relations emerged and various types of state capacity remained weak, Chinese FDI rose in state investments, which occurred during the Arroyo administration. However, the realization of these state investments were hindered due to low-levels of infrastructural power. Numerous corruption scandals and limited bureaucratic coherence discouraged private investments while illicit capital remained low due to the available legal avenues. Conversely, when conflictual relations occurred but state capacity improved modestly across the various types, Chinese FDI in state investments fell, as seen during the Aquino administration. In response, Aquino pursued alternative foreign and domestic investors for the large-scale projects. The improvement of state capacity during his time led to an increase of private investments. Illicit capital rose because of the conflictual relations between the Philippines and China. While there was an attempt to punish illicit capital in the extractive sector, low-levels of coercive capacity made enforcement ineffective. Yet again, when cooperative relations became dominant alongside increased levels of state capacity of various types, state and private investments rose, as seen presently during the Duterte administration. While Duterte's rapproachment with the PRC encouraged Chinese state investments to negotiate with the Philippine government once again, more stable economic institutions inherited during Aquino's time continue to attract private investments. Illicit capital in Duterte's administration continues but appears to be dwindling due to the available legal routes.

\section{Analytical framework}

Figure 1 summarizes the analytical framework of the paper: (1) The explanatory factor of inter-state relations divided in conflictual or cooperative; (2) outcome of the rise or fall of Chinese FDI disaggregated in state, private, or illicit capital; and (3) the intervening factor of types of state capacity-fiscal, coercive, legal-administrative, and infrastructural power. Table 1 summarizes the different concepts, their variation, their operationalization, their measurement as well as their expected hypothetical relations

Explanatory factor-inter-relations. Inter-state relations represent the state of the political relationship between countries. In 
international relations theory, inter-state relations can range from cooperative to conflictual. From trade embargos and international condemnation to full-scale wars (Simmons, 2005, p 825, Walt, 1990, p 31), conflictual relations represent a negative relationship. Conversely, built on different forms of joint military agreements, inter-cultural exchange, and preferential trading status (Moravcsik, 2013, p 81), cooperative relations indicate a positive relationship, ranging from an amicable friendly status to a comprehensive military alliance.

Past empirical research suggests that conflictual relations can severe economic relations between countries, leading to decreased FDI to the host country. Specifically, Simmons (2005, p 827) argues that territorial disputes, as a form of inter-state conflict, limit property rights, derail jurisdictional control, and create policy uncertainty, thereby generating a decrease in bilateral trade and FDI opportunities. Similarly, Nigh (1986, p 104) posits that whether or not companies invest depend largely upon the sending country's general perception of "conflictive inter-nation events" in

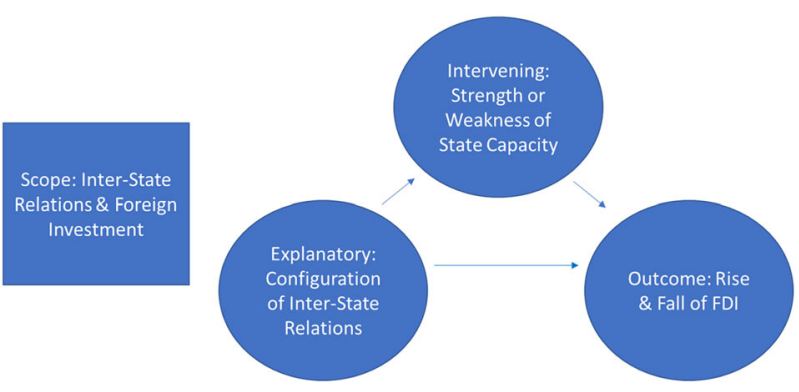

Fig. 1 Summary of the analytical framework the host country. He finds that international conflict decreases US FDI while cooperation increases it. Still, other international business and IR scholars present alternative perspectives on this relationship. In particular, Olibe and Crumbley (1997, p 346) argue that they could not find any consistent correlation between political risks, a composite index that includes the host country's likelihood to expropriate foreign property, and FDI inflows. Moreover, Li (2008, p 57) also shows that investment decisions largely depend on experiencing political risks, which means that the initial conflict between states might not even affect existing investments and future decisions.

Nevertheless, due to growing complexity of corporations and the global economy, conflictual relations do not necessarily inhibit the rise of FDI. For example, Taiwanese and Japanese investments in the PRC continue to rise despite numerous disputes over territorial claims and wartime atrocities. In the Middle East, Israel remains one of biggest capital exporters in the region despite its conflictual relations with most Islamic states. Some forms of FDI tied to sovereign wealth, developmental assistance, and projects with state enterprises can be constrained by conflictual relations. Similarly, a host country that does not or fails to differentiate between the sending country's state and private companies can similarly limit investment inflows. Most obvious of all, the occurrence of wars between states constrains FDI because political actors focus on wartime mobilization.

Conflictual. When conflictual relations emerge, sending and host countries can respond by increasing or decreasing the amount of FDI inflows. There are two possible outcomes, which represent the debate on inter-state relations and FDI. On one hand, some scholars argue that sending countries inhibit the amount of FDI inflows to host countries in order to acquire political concessions

\section{Table 1 Summary of the explanatory and intervening factors}

\begin{tabular}{|c|c|c|c|c|}
\hline Factors & $\begin{array}{l}\text { Type \& } \\
\text { Variation }\end{array}$ & Operationalization & Assessment or Measurement & Hypothetical Relations on FDI \\
\hline $\begin{array}{l}\text { Explanatory: } \\
\text { Interstate } \\
\text { Relations }\end{array}$ & Conflictual & $\begin{array}{l}\text { Antagonistic or competitive } \\
\text { relations between two states }\end{array}$ & $\begin{array}{l}\text { Antagonistic pronouncements, } \\
\text { retracted agreements }\end{array}$ & $\begin{array}{l}\text { A. Hinders state investment agreements. } \\
\text { B. At best, it creates an apolitical for private } \\
\text { investments } \\
\text { C. At worst, it forms an antagonistic } \\
\text { environment for private investments }\end{array}$ \\
\hline $\begin{array}{l}\text { Explanatory: } \\
\text { Interstate } \\
\text { Relations }\end{array}$ & Cooperative & $\begin{array}{l}\text { Amicable or friendly relations } \\
\text { between two states }\end{array}$ & $\begin{array}{l}\text { Friendly pronouncements, } \\
\text { agreements and political } \\
\text { treaties }\end{array}$ & $\begin{array}{l}\text { A. Encourages agreements on state } \\
\text { investments } \\
\text { B. Creates an encouraging political } \\
\text { environment for private investments }\end{array}$ \\
\hline $\begin{array}{l}\text { Intervening: } \\
\text { State } \\
\text { Capacity }\end{array}$ & $\begin{array}{l}\text { Fiscal-High, } \\
\text { Medium, or Low }\end{array}$ & $\begin{array}{l}\text { State's ability to extract rents from } \\
\text { the population }\end{array}$ & $\begin{array}{l}\text { Proportion of GDP from } \\
\text { taxation, or total amount of } \\
\text { taxation from revenue } \\
\text { mobilization }\end{array}$ & $\begin{array}{l}\text { A. The lower the fiscal capacity, the higher } \\
\text { likelihood of lost taxation revenues } \\
\text { B. The higher the fiscal capacity, the more the } \\
\text { the host state benefits from the different } \\
\text { kinds of investments. }\end{array}$ \\
\hline $\begin{array}{l}\text { Intervening: } \\
\text { State } \\
\text { Capacity }\end{array}$ & $\begin{array}{l}\text { Administrative- } \\
\text { Legal-High, } \\
\text { Medium, or Low }\end{array}$ & $\begin{array}{l}\text { Bureaucracy and organizational } \\
\text { coherence of the state to facilitate } \\
\text { rules, procedures, and ideas }\end{array}$ & $\begin{array}{l}\text { Ease of doing business and IMD } \\
\text { competitiveness rate }\end{array}$ & $\begin{array}{l}\text { A. The lower the administrative-legal } \\
\text { capacity, the higher cut of rent-seeking elites } \\
\text { B. The higher the administrative-legal } \\
\text { capacity, the more it encourages private } \\
\text { investments }\end{array}$ \\
\hline $\begin{array}{l}\text { Intervening: } \\
\text { State } \\
\text { Capacity }\end{array}$ & $\begin{array}{l}\text { Coercive-High, } \\
\text { Medium, or Low }\end{array}$ & $\begin{array}{l}\text { Military capability to defend the } \\
\text { state from external and internal } \\
\text { threats }\end{array}$ & $\begin{array}{l}\text { Military's budget, size, and } \\
\text { technological sophistication }\end{array}$ & $\begin{array}{l}\text { A. The higher the coercive capacity, the more } \\
\text { it discourages illicit capital. } \\
\text { B. The lower the coercive capacity, the higher } \\
\text { the rate of illicit capital. }\end{array}$ \\
\hline $\begin{array}{l}\text { Intervening: } \\
\text { State } \\
\text { Capacity }\end{array}$ & $\begin{array}{l}\text { Infrastructural } \\
\text { Power-High, } \\
\text { Medium, or Low }\end{array}$ & $\begin{array}{l}\text { The state's capability to penetrate } \\
\text { civil society through social } \\
\text { programs }\end{array}$ & $\begin{array}{l}\text { State spending on society and } \\
\text { support from social groups }\end{array}$ & $\begin{array}{l}\text { A. The higher the infrastructural power, the } \\
\text { more the administration can complete state } \\
\text { and private investment deals. } \\
\text { B. The lower the infrastructural power, the } \\
\text { higher the likelihood of elite and social } \\
\text { movement opposition to state investments }\end{array}$ \\
\hline
\end{tabular}


(Hirschman, 1980, p 27). On the other, scholars say that sending countries can increase the amount of FDI inflows in order to attain the same goal (Gilpin, 2016, p 172). The measure for conflictual relations includes the number of retracted trade agreements, political treatises, and antagonistic political statements. In addition, conflictual relations can also lead to the absence of opportunities for state investments and an antagonistic investing environment for private investments. For the latter, the company's profitability and other economic considerations can and may outweigh the antagonistic political environment.

Cooperative. When cooperative relations occur, sending and host countries work in a functional consonance to increase FDI inflows. The sending country government may give subsidies to state owned and private companies to invest or knit together aid packages to finance projects in the host country (Moravcsik, 2013, p 27). Similarly, the host country can implement policies that can encourage its companies and individuals to make business deals with entities of the sending country. For these actions to occur, the political relationship of the sending and the host countries become a considerable driver of investments (Moravcsik, 2013, p 31). The cooperative relations can also lead to a preferential investing environment for private investments. Other factors such as the compatibility of economies, the number of foreign competitors, and the openness of the host country to foreign capital may affect the sending country's investment (Dunning, 1998, p 6 ). While the positive political relationship can lead to the rise of state and private investments, the realization of these investments mainly depends on the domestic social forces of the host country. The measure for cooperative relations includes the number of trade agreements, political treaties, and friendly international pronouncements.

Outcome-rise or fall of types of capital. FDI takes on different modes of entry ranging from the complete or partial takeover of existing companies or the full establishment of new firms in another country. Due to the growing importance of financial markets and state funding, FDI needs to be differentiated from foreign portfolio investments (FPI) and ODA. Unlike FPI, which takes the form of stock and debt securities in order to acquire a temporary shareholder status, FDI exerts managerial control over, and long-term commitments in, the companies and assets through purchasing equities or establishing greenfield projects (Jensen et al., 2012, p 1). In some situations, FDI projects can acquire external funding from the ODA budgets of sending countries or international developmental agencies (Bräutigam, 2011, p 754, Schraeder et al., 1998, p 304). In others, ODA-funded projects can become FDI after the project's completion if and when sending and host countries agree on equity returns (Camba 2017, p 4). Most smaller state or private investments usually do not have ODA funding.

In my paper, the outcome is the rise or fall of Chinese state, private, and illicit capital in the Philippines. ${ }^{5}$ What counts as "rise" or "fall" will be judged quantitatively and qualitatively by comparing the aggregate amount of Chinese FDI across the three administrations. ${ }^{6}$ State investment data counts the aggregated amount of invested or committed funds in the Philippines by PRC entities. ${ }^{7}$ While the absolute amount of FDI can be incomparable across administrations due to the continuous growth of China's capital exports in the world, I also use the proportion of Chinese FDI that went to the Philippines to those of ASEAN countries. ${ }^{8}$

While there is a debate on the similarities and differences of Chinese and global FDI, one way to resolve the dispute is to differentiate the logics of Chinese FDI across state, private, and illicit types. There is variation among Chinese companies in the world, pointing to asset specificity, sectoral distribution, and the size of investments. It is well-known that there is no single Chinese investor, but instead a multiplicity of national and regional state oriented enterprises (SOE), provincial entrepreneurs, and private investors (Bräutigam, 2009, p 15; Hung, 2008, $\mathrm{p}$ 132). Quantitative studies on this debate tend to conflate Chinese investments along national lines, examining their aggregated general behavior. Conversely, qualitative works disaggregate the various Chinese state departments, national and regional SOEs, and private citizens, examining their various interactions with host country actors (Wang, 2002, p 195). From another direction, others examine how the host country's "people, places, and ideas" react to Chinese entities (Nyíri and Tan, 2016, p 3 ). Using insights from these works, I generate three types of Chinese FDI: (1) state investments; (2) private investments; and (3) illicit capital.

State investments. Equity or greenfield projects by companies owned by or reliant on sending countries count as state investments. These projects are often funded by the sending country's sovereign wealth funds or developmental aid tied to some strategic or domestic objective (Arase, 1995, p 13): disbursing surplus goods and service to generate more economic activity, subsidies to the sending country's state or private companies, or to acquire strategic natural resources or crucial political returns (Alesina and Dollar, 2000, p 55). During the Cold War period, the United States (US) government funded aid organizations and developmental projects to promote anti-communist and liberal democratic principles. Similarly, Mao Zedong's China and the Union of Socialist Soviet Republic sent developmental aid to numerous satellite and host countries. While state investments depend on some degree of profitability, the primary objectives remain political. The origin and expansion of these investments depend on the political relationship between the sending and host countries.

Chinese state investments usually occur through agreements to build infrastructures and mega facilities via ODA. The standards for Chinese state investments include the primary role of Chinese SOEs, labor and good requirements, and the loan's potential political-economic return. While private Chinese companies can take leading roles in projects, the Chinese state is the primary actor for deciding which projects to fund and under what political situation. Therefore, since the Chinese state ensures funding, a cooperative or friendly relation is a requirement. As a result, conflictual relations between China and the host country discourage this specific type of investment.

Private investments. Private investments pertain to capital owned by sending country citizens located in, or committed to, greenfield investments or joint ventures in the host country. Some examples of private investments include huge multinational companies with international shareholders or small and medium enterprises of sending countries (Dunning, 2003). For these investors, maximizing profitability and minimizing political risk become the primary considerations for investing (Calvo et al., 1993, p 110). In the literature on foreign investment determinants, the supply and demand sides explain the motivations and dynamics of private investments. For the supply side, crucial factors include investment competitiveness, political stability, and the host country's openness (Culem, 1988, p 886, Lunn, 1983, p 392). For the demand side, the primary factor is the capacity and willingness of the host country entities to induce investors (Bandelj, 2008, p 3, 2009, p 130). Needless to say, private investments differ not only by their size and amount of capital, but also on their access to crucial networks in sending and host countries. 
PRC entities who sent or committed funds to the Philippines are considered private investors. Private investments work within the rules and structures in the host country, often with state bureaucrats or local business groups, reversing the relationship found in state investments. Because these specific arrangements are often smaller, invest in non-strategic sectors, and value profit making above all else, these investments can continue and be profitable even in the presence of inter-state conflict. Despite having an ostensibly apolitical and profit-motivated behavior, private investments nevertheless contend with lower risk and potentially commit more if and when inter-state relations are cooperative. More crucial than inter-state relations, the host state's capacity to limit rent-seeking, facilitate market engagement, and safeguard property rights is vital to investors.

Illicit capital. Though conventionally not considered foreign investment, illicit capital is foreign funding that circumvents the legal avenues of the host country in order to fund some sort of economic activity (see Hentschel et al., 2002, p 8). These cases usually occur when sending country investors have host country partners who are politically strong enough to evade the national regulatory institutions and who typically operate in extractive industries, illegal logging, and the informal retail economy. In this case, investors are motivated by the presence of cheap natural resources, the absence of a legal venue to invest in key sectors, and the host country's regulatory weakness.

Illicit Chinese capital manifests when PRC investors fund the host country's regional politicians or local firms to illegally operate in strategic yet controversial sectors. Inter-state conflict and weak state capacity encourage Chinese investors to divert their potential ventures from the formal to the illicit economy. As Chinese investors provide capital while host country actors vend political access, many of these investments can be found in the host country's peripheral and informal economies. A case of illicit investments is the illegal extraction and smuggling of minerals. In the Philippines, these investments funded artisanal small-scale mining (ASM) infrastructures because of the South China Sea dispute and the weak regulatory capacity of Philippine institutions. Illicit capital is not exclusive to Chinese investments in the extractive sector. In broad terms, other foreign investors and Chinese entities can have illicit capital ventures in logging, agriculture, and many other sectors.

Intervening factor-state capacity. Charles Tilly (1992, p 20) famously suggests that the state's organizational apparatus, known as state capacity, can become stronger through the occurrence and persistence of wars. Specifically, Tilly shows that the mobilization and consolidation of the state's bureaucracy in the wartime period strengthens the organizational apparatus to extract taxation, implement programs, and adapt to new situations. Because citizens have little access to the means of protection, states correspondingly extend protection while simultaneously extracting rent from citizens. However, Tilly solely discusses state capacity in the context of European state formation. He therefore misses the relative absence of a Westphalian inter-state system in the post-war context of the developing world. To address this gap, Thies (2005, p 463) argues that even though inter-state wars have declined in the postwar context, the trepidation caused by inter-state rivalries have the potential to erupt into full-blown wars. As a result, postcolonial leaders do have the impetus to extract rent from their societies to expand the state's capacity (Kisangani and Pickering, 2014, p 189).

In this sense, trepidation occurs if and when inter-state relations become conflictual. The threat of war can cause trepidation and thus lead to the improvement of state capacity. When relations remain friendly, trepidation does little to influence state actors, which could lead to an intensification of rent-seeking due to a sense of security. While a system of juridical sovereignty exists in postwar Southeast Asia, examining how state capacity and inter-state relations interact can offer potential insights to understanding the direction and behavior of foreign investments. In this sense, state capacity has conventionally been measured by fiscal, coercive, and legal-administrative capacities (Hanson and Sigman, 2013, p 4). This conventional formulation of state capacity assumes that reforms will make the economy attractive for domestic and foreign investments, expand the state's revenue stream, and increase the competitiveness among businesses. While I describe three types of capacities that pertain to the state, I add a final type which comes from the state's relationship with society, shaping the implementation of programs and the realization of investments.

Fiscal capacity. Fiscal capacity measures the state's government revenue collections. As Slater (2010) points out, "revenue collection may not be the perfect barometer for state power, but it is the next best thing" (cited in Larsson, 2013, p 338). For Larsson (2013, p 4), two important measures stood out for fiscal capacity. First is the ratio of total tax revenues to gross domestic product and the total amount of taxation in revenue mobilization. Second is the relative political extraction, which looks at the state's overall real level of taxation vis-à-vis its expected level of taxation. High or low-levels of fiscal capacity do not directly affect the negotiation for or realization of state and private investments. It does, however, impact the state's revenue streams from both investments.

Coercive capacity. This type focuses on the military's capability to defend the internal and external sovereignty: limiting insurgency, safeguarding resources, and preventing inter-border invasions. Researchers focus on military size, budget, and technological sophistication to gauge coercive capacity (see Hanson and Sigman, 2013, p 7). While coercive capacity seems straightforward, assessing the strength of armed forces across different countries can be tricky. A larger military size or bigger proportion of the budget relative to the state's GDP may not necessarily mean a more effective military force. Some other military institutions, which rely on external funding or foreign defense apparatuses, usually evade such measures.

Legal-administrative capacity. Legal-administrative capacity looks at the regulatory capacity, legal power, and organizational coherence to administer rules, implement decisions, and ensure procedural predictability (Larsson, 2013, p 340). While there are debatable standards on legal-administrative capacity, the ease of doing business, which pertains to the host country's readiness to follow business rules, and the degree of competition, which describes business competitiveness to ensure innovation, are usually used. This kind of capacity mainly affects private investments. High-levels of legal-administrative capacity limits the chances of political elites or corrupt bureaucrats to seek rent. In addition, the higher the level of this capacity, the more that private investments are encouraged because of business predictability.

Infrastructural power. Mann (1984, p 185) describes this as the "bureaucratic state," a type of state with high organizational capacity that can only succeed through civil society. As firms facilitated by the national framework advance their operations in often politically fragile and socially contested environments, the only means by which the state can gain legitimacy in the eyes of 
its citizens is through cooperation with civil society and communities. For this reason, the social contract with communities must be obtained, legitimated, and maintained by the state through consultation and consent (Bebbington and Bury, 2013, p 12). Standards for this kind of capacity include the ratio of the state's spending on society and the overall approval rating of President and the administration. Infrastructural power does not affect the negotiation for state investments nor does it directly affect the decision making of private investments. However, the lower the levels of infrastructural power, the higher the likelihood for political opposition and social mobilization that will derail state and private investments. Furthermore, extremely low levels of infrastructural power creates too much political risk for state and private investments.

Methods of data collection. I employ a primarily qualitative research design that teases out the mechanisms linking the interstate relations, state capacity, and the kinds of Chinese FDI. Although limited by the focus on a specific country and several administrations, a case study approach allows for the in-depth mapping of actors, tracing of processes, and detailed accounting of events. In addition, case studies enable the exploration and analysis of potential unobserved pathways and mechanisms that large-n designs would otherwise overlook. Issues such as sequences, the direction of causality, and the interaction of different variables consolidate into a coherent narrative.

At the start of administration, I analyze inter-state relations between the Philippines and China using key-informant interviews with political party members, government officials, and Chinese investors. Afterwards, I examine how inter-state relations and the level of state capacity affect each type of FDI. To accurately gauge state capacity, I draw from a collection of descriptive statistics by different organizations. Other scholars have used these numbers to qualify and conceptually clarify the levels of fiscal, administrative-legal, and coercive capacities of the state. These reports include measurements of the ease of doing business, international competitive standards, military spending, and survey data on the population's net satisfaction with the government. In addition, interviews with Philippine officials from various departments, and other analysts will verify these initial measures. For "infrastructural power, a qualitative assessment has been made through interviews with civil society actors along with the use of descriptive survey data. ${ }^{9}$
To assess the rise or fall of Chinese FDI in the administrations, the paper draws from Chinese, international, and host country data sources. Data on Chinese outward FDI in the Philippines present different information, but there are three important sources, which differ in their construction and use of data. In the Chinese Global Investment Tracker (CGIT) dataset, which tracks investment commitments by Chinese multinational companies worldwide, Chinese FDI currently sits at US\$4.6 billion in the second quarter of 2016. ${ }^{10}$ Conversely, data from China's Ministry of Commerce (MOFCOM), which looks at FDI stock or the estimate market value of Chinese enterprises through their fixed capital, reserve liquidities, and the liabilities of their subsidiaries, presents a similarly low amount in the Philippines vis-à-vis other ASEAN states. ${ }^{11}$ A combination of the CGIT and MOFCOM data can be seen in Fig. 2. Comparing China's data with host country sources, data from the Philippine government shows an analogous low amount (see Fig. 3). ${ }^{12}$ Host country data shows Chinese FDI inflows and mainly draws from the seven investment promotion agencies (IPA). In-depth interviews with Chinese investors from state and private companies were also used to supplement the descriptive data. For illicit capital, I draw on previous research I conducted while based in the Philippines in the summers of 2014 and 2015. I conducted interviews with local politicians, miners, and community members at Chinese-funded ASM sites in Zambales, Cagayan, and Compostela Valley. ${ }^{13}$

While official data verifies the amount of FDI, the perspectives of different informants account for the dynamics of Chinese state, private, and illicit capital across these administrations. While these measures will be numerically less precise, largely due to the use of diverse datasets and the use of qualitative data, they can at least capture the rise and fall of Chinese FDI more dynamically compared to the sole use of aggregate statistical data. Though official statistics describe the amount of state and private investments, only interviews can capture the movement of illicit capital. In addition, there is also a possibility for Chinese money to be laundered in Sino-Philippine banks. Specifically, investors can convert private Chinese money into domestic Philippine capital, leading to an underestimation of the amount of Chinese FDI in official records. It should be noted that this is phenomena is not exclusive to Chinese investments, but one that has been carefully noted in the literature on states with weak institutions. This possibility, though crucial and must be investigated by future researchers, remains outside the scope of the paper.

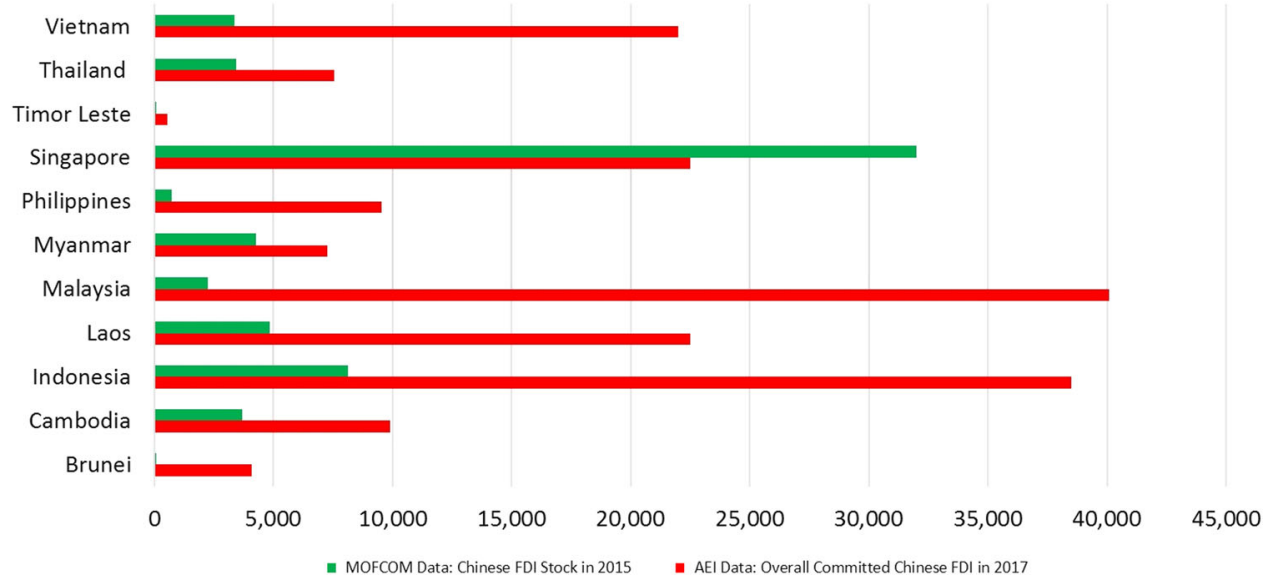

Fig. 2 Chinese FDI in Southeast Asia. Source: The Chinese Ministry of Commerce's 2015 Statistical Bulletin of China's Outward Investments (2015) and the American Enterprise Institute's Chinese Global Investment Tracker, url: http://www.aei.org/china-global-investment-tracker/ 


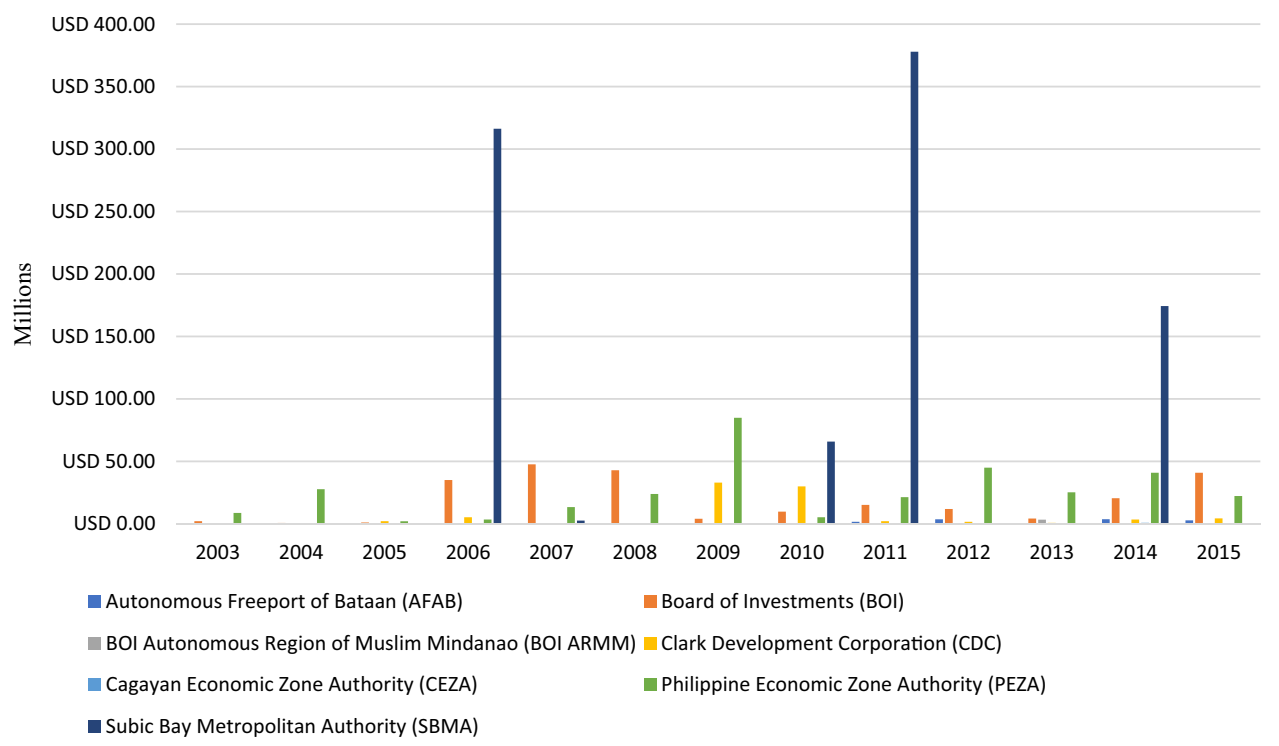

Fig. 3 Chinese FDI in the Philippine Investment Promotion Agencies, 2003-2015. Source: Modified documents from Philippine Statistical Office and Philippine Investment Promotion Agencies

\section{Arroyo's romance with chinese aid and investments (2001-2010)}

Cooperative relations. After the discontinued presidency of Joseph Estrada (1998-2001), Arroyo was the first Philippine President to recognize China's inevitable and clear role in the global economy. During the first year of her full term, she attended the 9th APEC Economic Leaders Meeting in Shanghai and conducted bilateral talks with President Jiang Zemin (1993-2003). She further visited Hong Kong afterwards, culminating in an official state visit to China from 29 to 31 October 2001. In 2002, the Philippine and Chinese Foreign Ministries held a series of celebrations, which Arroyo attended (Shan, 2012). As the Philippine General Consulate in Shanghai opened in the same year, the Philippine Navy Fleet under Arroyo's command visited China for the first time in history.

In addition to Arroyo's diplomatic visits, China and the Philippines strengthened their commercial and economic ties (Shan, 2012). Former Chairman Li Peng (1998-2003) of the Standing Committee of the National People's Congress visited the Philippines, signed the "MOU on cooperation in Tourism" with China. Cebu Pacific, a Philippine-based airline, opened new round-trip flights between Manila and Guangzhou. In 2004, Arroyo attended the Third International Conference of Asian Political Parties in Beijing, resulting in the Sino-Philippine Fishery Cooperation, the Implementation Plan of Tourism, and the initial discussion of the Joint Maritime Seismic Undertaking (JMSU), which was signed in 2005 (Bower, 2010, p 2). The JMSU allowed China to explore the bodies of water for hydrocarbons within 200-mile exclusive economic zone boundaries of the Philippines (Bower, 2010, p 4).

As a total of 65 other bilateral agreements were signed during her time, with contents ranging from agriculture and fisheries to infrastructural construction, analysts recognized a strong political relationship develop between the Philippines and China. In addition, more macroeconomic exchanges such as a bilateral currency swap agreement worth US\$1 billion also occurred in 2003, coinciding with the opening of the First Philippine Trade Fair (Shan, 2012). Apart from the numerous high-level exchange between state leaders, Arroyo attended the Boao Forum for Asia in 2007, which was a meeting held among the high-level leaders of East-Southeast Asia to discuss the most important economic issues and commercial interests at that time. As Arroyo continued to placate and strengthen ties with the PRC in various ways, these moves signaled the shelving of the South China Sea dispute in favor of China's state investments.

State investments-significant rise and nonrealization. Arroyo's foreign policy overtures ultimately culminated in more than 20 state investments in the Philippine economy. While the Chinese Export-Import Bank's US $\$ 1.2$ billion loan for the North Luzon Rail project (North Rail) and the highly controversial Zhongxing Semiconductor Co. (ZTE) (Landingin, 2010) represented the most controversial deals of her administrations, there were also other less publicized state investments in mining, agriculture, banking, and education.

In 2004, the Philippines and China agreed on a US\$503 million deal to build a 32-kilometer railway designed to link Metro Manila, Northern Luzon cities, and key seaports. At that time, the railway was called "the largest Chinese project in Southeast Asia," which boasted 20-year loan with a 3\% annual interest (Landingin 2010, p 88). Officials from Manila dubbed it as the North Luzon railway, which came with the real promise to transport hundreds of thousands of passengers from other cities into Metro Manila. Japanese and European companies competed for the project but the China National Machinery and Equipment Corporation, which was led by Sinomach Co., eventually won the bid. In the ZTE project, former Secretary Leandro Mendoza of the Philippine Department of Transportation and Communication and ZTE Vice President Yu Yong (Landingin, 2010, p 90) agreed on a contract worth US\$329.5 million. The ZTE investment was designed to upgrade National Broadcasting Authority's infrastructure and communication technology. Former First Gentleman Mike Arroyo and his allies in the administration spearheaded ZTE project, defeating Philippine-based Amsterdam Holdings and American-funded Arescom International.

Along with many small and medium-sized mining companies that went on to form joint ventures with Philippine citizens, the Jinchuan Non-Ferrous Metal Corp. explored the possibility of investing in the Nonoc Mines in the province of Surigao. Similarly, the Diwalwal mine in Compostela Valley was offered to one of ZTE's branches that invest in mines (Davao Today, 2006). In agriculture, the Arroyo government signed 18 land lease agreements with Chinese state and private agribusinesses. In the most controversial project, the Department of Agriculture (DA), 
Agrarian Reform, and Environment and Natural Resources (DENR), signed an agreement with People's Government of Jilin, China Development Bank, and Fuhua Agricultural Science and Technology Development Co. to acquire a 50-year lease for 1 million hectares of land (De la Cruz, 2010). Other projects such as the NBN-Cyber Education deal and numerous port projects were also started during Arroyo (Senate Economic Planning Office, 2008). As such, cooperative relations between the PRC and the Philippines explain these particular successful negotiation and agreement of Chinese state investments across different sectors. In an interview with a key official who worked directly under Arroyo's Office of the President's Overseas Developmental Aid Office, he explained, “Arroyo's government barely had the budget for big projects... much less for bigger infrastructures... so she was looking for ways to get people jobs and investments in the country." 14

Though cooperative relations resulted in numerous ODAfunded investments between the states, agreements and implementation phases are different from the realization of the projects. In order to understand the failure of China and the Philippines to complete these projects, it is crucial to analyze Arroyo's rise to power. Her incumbency was built on the extraconstitutional elite-led "People Power II" in 2001 that relied on porous democratic legitimacy, which was threatened by Estrada's successive "People Power III" in 2002. ${ }^{15}$ After breaking her promise of setting aside the 2004 elections, Arroyo not only ran for re-election but won amidst widespread accounts of alleged cheating, casting a shadow of doubt over her presidency (Hutchcroft, 2008, p 145). As a result, opposition elites from various contending political parties and progressive social movements mobilized to depose Arroyo and oppose Chinese investments that her administration backed. Multiple rallies and protests against ZTE occurred alongside the political opposition's legislative blockades, which led to the project's eventual retraction in October 2007. In 2008, North Rail met a similar fate shortly after drawn out court hearings and mass mobilizations. Near the end of her term, the 18 agricultural projects were suspended by the Supreme Court and the 2 multi-billion dollar mining investments were canceled because of the opposition from local elites (Alve, 2011). Civil society actors, progressive left parties, and people's organizations across the country also opposed these investments.

The fate of Chinese state investments in the Philippines can be explained in part by Arroyo's weak infrastructural power, or the absence of a political linkage between government policies and the social needs of citizens. Arroyo's net satisfaction ratings in 2004 spiraled downward from +25 to -3 (Social Weather Stations, 2017). Similarly, her "second term's" (2004-2010) net satisfaction ratings vacillated between -5 and -52 (Pabico, 2008). Furthermore, the unemployment rate reached $11.2 \%$, or a staggering 11.4 million unemployed Filipinos, which surpassed Estrada's already abysmal rate by 3.1 million (Ibon 2010) while poverty incidences reached $13 \%$ of the population or 4.7 million people in 2008. Moreover, despite the fact that Arroyo created jobs in the business process outsourcing sector, manufacturing dwindled to $21.8 \%$ of the GDP while agriculture's share decreased to $18.1 \%$ (Ibon, 2010). Balancing between appeasing her allies and spearheading neoliberal restructuring, Arroyo's policies also reinforced the position of Filipino oligarchs, vastly polarizing the already unequal the wealth gap. As a result, household incomes fell by $20 \%$ across all income brackets (Ibon, 2010). Nominal income increased by $19 \%$ but inflation rose even higher by $38 \%$. National deficit reached US $\$ 26$ billion dollars from 2001 to 2010 despite using a higher proportion of the GDP to pay for previous debts than all the post-Marcos governments combined (Pabico, 2008).
Private investments-low capacity, weak bureaucracy. As a former American colony with high-levels of English proficiency and a consumption-driven economy that needed imported manufacturing goods, the Philippines was a potentially important market for China. While Japanese capital dominated much of the economy, the Philippines received marginal levels of Japanese investments in the 1990 s compared to other middle-income Southeast Asian states. In addition, the Philippines was relatively unaffected by the Asian Financial Crisis in 1997 due to its the largely inward and consumption-driven economy.

As a result of these economic indicators, cooperative relations encouraged private investments during the early phases of China's going out policy. In an interview with a Chinese investor in bag manufacturing, she said, "everybody in China wanted to go to the Philippines to invest in the early 2000s because of the initial warming of the relationship between Beijing and the Manila... but also because the Japanese were not as dominant as in other places." ${ }^{16}$ She further noted, "compared to the other middleincome Southeast Asian states, the Philippines was a durable country.. so Chinese banks were willing to give low cost and zero interest loans to those moving to the Philippines during the time of Macapagal." ${ }^{17}$ At the same time, Philippine national officials sold to Chinese businesses the idea of an "open and free economy that could ensure predictability, a pro-business environment, and democratic regime." ${ }^{18}$ However, Chinese investors trusted the wholesale image painted by the Philippine officials and had little idea that there were serious structural problems.

Arroyo's administration was characterized by high-levels of rent seeking, leading to higher political risks and limited business predictability for foreign investors (Ibon, 2010; Pabico, 2008). Poor institutions with weakened administrative-legal, fiscal, and infrastructural power coupled with persistent internal divisions among elites refracted rampant rent-seeking practices from top to the bottom, negatively affecting businesses in the IPA designated export processing zones. In the Ease of Business ranking, the Philippines ranked 144 at the bottom 1/3 of countries around the world (Montecillo, 2013). For bureaucrats, rules and regulations became increasingly difficult to implement because of political appointees or corrupt public official networks within the political machinery. Indeed, this was the experience of many Chinese and international private investors in the Philippine private sector. In an interview with a Chinese investor in a Philippine call center, she described Arroyo's officials as "asking for money at every turn of the process... from this permit, to this permit, to this permit, and you'll be bled dry even before you start doing business." 19 Similarly, low-level infrastructural power also constrained investor predictability. A Filipino Chinese businessman in a shoe business said, "there were always rallies against her [Arroyo] and that delayed the processes in Manila... there were also her enemies in the other government branches." 20 In the IMD World competitiveness report, the Philippines scored a meager 3.8, far below the average score of 5 (IMD 2016).

In the midst of this disarray, Arroyo attempted to expand state capacity. Specifically, in terms of fiscal capacity, she made an already regressive taxation system more regressive, focusing on the passage of the value added tax law in 2007, which increased the consumption tax for all classes. However, due to the limitations of income, property, and capital gains taxes, the Bureau of Income and Revenues was unable to acquire taxes from bigger and more important sources: huge Filipino corporations, political elites, and landed classes (Camba, 2016b; Ibon, 2010; Hutchcroft, 2008). In other words, while revenues drawn from taxation remained high, the vast majority of the sources came from the middle and working classes. In addition, government corporations were largely inefficient. For example, Philippine Government Owned Corporations only remitted US\$1.6 billion 
dollars during Arroyo, but this amount eventually doubled during Aquino's time. Her weak capacity to bolster state revenues and finance social programs exacerbated her already dwindling legitimacy. Because Arroyo could not afford to displease her powerful supporters, she had to turn a blind eye to numerous dubious practices, leading to a surge of rent seeking across government departments from top to bottom (Hutchcroft 2008). An interview with a government official who served during Arroyo said, "topping off projects by 5 to $10 \%$ was normal in his [the official's] 20 years of service, but during Arroyo officials increased their cut by 40 to $50 \%$ more." ${ }^{21}$

In one particular instance, Arroyo appeased various factions in the Armed Forces of the Philippines (AFP) at once by funneling funding for schools and development programs to the AFP's budget to wage war against the New People's Army, the Moro Islamic Liberation Front, and various secessionist movements (Ibon, 2010). Arroyo further gave or overlooked the AFP's activities in the frontier regions to conduct their operations with little civilian oversight, which in turn led to a rise of the extra judicial killings of activists, communities, and local opposition figures (Ibon, 2010). ${ }^{22}$ Nevertheless, despite the higher budget and fewer political constraints, the Philippine military was only capable enough to contend with internal opposition, but lacked the capability to effectively handle external threats. Specifically, coercive capacity remained at a low-level as generals "regularly became chief of staff every quarter or so while the overall technological sophistication of the Philippine war machine remained low." ${ }^{33}$ Since Arroyo had to placate the elites and generals, her government's administrative-legal capacity was severely compromised. As state budget were used by local opposition and specific military leaders for personal gain, the funding for already weakened social programs further deteriorated (Landingin, 2010).

Illicit capital-limited and contained. Illicit capital originating in retail, services, and the extractive sector preceded Arroyo's time. During Corazon Aquino's presidency (1986-1992), international organizations and multinational mining companies pressured the Philippine government to liberalize the mining sector (Nem Singh and Camba, 2016, p 52). These efforts in the early 1990s eventually led to the passage of the Philippine Mining Act 1995 (RA 7942). As Canadian and Australian mining companies began to explore the Philippines in anticipation of RA 7942 (Camba 2015, p 297), pressure from regional actors and local governments led to the People's Mining Act of 1991 (RA 7076). Under certain conditions, the act empowers local governments to designate legitimate and protected small-scale mining operations within their locales such that these areas cannot be sequestered by large-scale mining operations. By some estimates, there are at least 300,000 miners in ASM gold mining in perhaps close to a thousand small-scale mining operations in the Philippines (Human Rights Watch, 2015), which was a significant increase from around 50,000 workers in a hundred ASM operations during the 1980s. There is also an unknown number of ASM workers in non-gold mines.

Due to the development of extractive technologies in the late 1990s (Camba, 2016b, p 72), ASM cannot really capture the variety of mineral operations in the 21 st century. While laborintensive, flexible, and community-centered, some of these operations also use advanced machineries and sophisticated technologies, receiving funding worth millions of dollars to conduct mineral extraction. In the Philippine case, full foreign ownership of mining companies remains a controversial political issue (Singh and Camba, 2016, p 53). Specifically, regional politicians interested in monopolizing the local economies and civil society are intent on reserving the use of Philippine resources for Filipinos. As a result, they easily unite against national moves to allow full foreign ownership.

The reopening of the Philippines' mining regime coincided with China's own capital exports in the early 2000s. While the weak state capacity of Arroyo government allowed Chinese investors to funnel illicit capital to regional and local politicians, the cooperative relations between the Philippines and China minimized their amount. In particular, during Arroyo's time, there were legal opportunities for Chinese companies to apply for mineral extraction, such as ZTE in Diwalwal and the Jinchuan Non-Ferrous Metal Corp in Nonoc Mines. As seen in Table 2, compiled shareholder data from Philippine Security Exchange Commission specifically shows that 34 Chinese mining companies legally applied for and started conducting business in the Philippines. In terms of capital stock, manpower, and technological sophistication, these Chinese mining companies paled in comparison to China's own major State-owned enterprises in Africa and the multinational mining companies operating across the world. Indeed, none of these Chinese mining companies in the Philippines were even comparable to the largest Filipino mining companies (Camba forthcoming). It is still possible to infer that illicit capital proliferated because local governments were given the power to oversee ASM licensing and safeguarding. Enabled by significant downward allocation of regulatory powers, ASM operators in 2014 told me that there were some illegal extractive activities during Arroyo's time.

In sum, cooperative relations between the Philippines and China led to the numerous state investment agreements, but weak infrastructural power effectively resulted in the non-completion of these projects. The Arroyo administration represents a case of weak state capacity across all four dimensions, leading to higher political risks and limited predictability for private investments. Though the opportunities were abundant, illicit capital was kept at a minimum due to the legal avenues presented to Chinese investors. By the end of her term, only one of the state investments was realized and few of the private investments continued.

\section{Aquino's stand in the South China Sea (2010-2016)}

Conflictual relations. The start of Aquino's term did not substantially deviate from Arroyo's foreign policy position. Indeed, foreign policy analyst Richard Heydarian suggested, "scholars often ignore that there were contingent circumstances on the part of the Philippine and Chinese officials that led to the downward turn of inter-state relations." 24 However, as one of Arroyo's fiercest political enemies during her term, Aquino was vindictive towards the previous administration's inner circles, though the more practical faction of his administration recognized the worth of Chinese aid and investments for key infrastructural projects. Specifically, an adviser of the Aquino administration noted, "in the initial agenda, China was proposed to fund and target around 10 potential large-scale investments." ${ }^{25}$ At first, Manila and Beijing initially planned to continue or even expand foreign investment and overseas aid, but when the Chinese navy stopped and almost detained a Philippine survey ship, talks came to an abrupt halt. ${ }^{26}$ In April 2012, a Philippine Navy plane spotted eight Chinese fishing vessels near the Scarborough Shoal, prompting the BRN Gregorio del Pilar to move in the vicinity. As the BRN attempted to arrest the fishing vessels, two Chinese navy ships arrived, resulting in a naval standoff (Santos, 2012).

The initial encounter snowballed into a foreign policy issue that impacted the entirety of Aquino's presidency. In response to the naval standoff, Aquino bitterly defended and defied the PRC's territorial claims over the South China Sea, leading to the 


\section{Table 2 A Partial List of Chinese mining companies in the Philippines, 2002-2015}

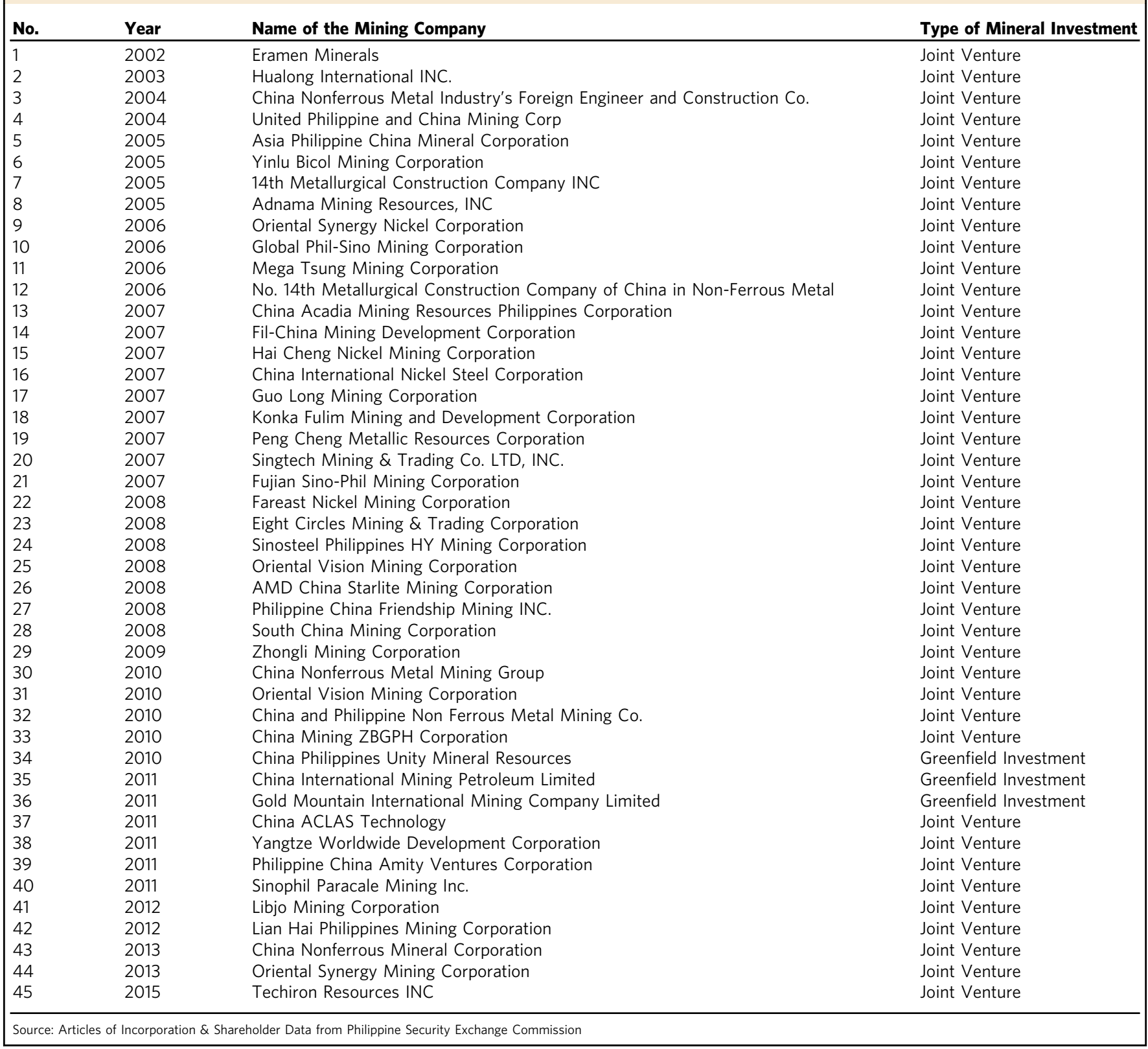

reaffirmation of the Philippines' stake in the South China Sea and the strengthened role of the United States in Southeast Asian affairs (De Castro, 2014, p 428). Indeed, Aquino's stance came at the time when then-US President Barack Obama announced his "Pivot to Asia" (De Castro, 2014, p 435), which occurred alongside the beginnings of the Transnational Pacific Partnership in 2012 and reflected the rising tensions in Southeast Asia (Capling and Ravenhill, 2011, p 559). Aquino rescinded natural resource agreements in the South China Sea and political treatises established by Arroyo (Camba, 2016a, p 7). Aquino's speech that likened China to Hitler's Germany and the Philippines to Czechoslovakia further angered Beijing (Bradsher, 2014). Despite China's economic and political threats via official government statements to Manila, the Philippines affirmed the Visiting Forces Agreement (VFA) with the United States in 2014 (De Castro, 2016a, p 165), conducted joint military exercises with the Australia (De Castro, 2014, p 440), bought billions of dollars' worth of military arms from the US (De Castro, 2014, p 433), called for numerous UN resolutions in the dispute (Heydarian, 2014), and criticized the Chinese publicly on numerous occasions (Bradsher, 2014). The disputes ultimately led to the Enhanced Defense Cooperation Agreement between the Philippines and United States (De Castro, 2016b, p 320), which enforced the 1951 Mutual Defense Treaty and the 1999 VFA agreement, and allowed US forces to build small infrastructures and operate in "agreed locations" (Tilghman, 2016). In 2014, the Philippine government began printing its own version of the Asia Pacific map, renaming the South China Sea the West Philippine Sea (Buszynski, 2012).

Like many other Southeast Asian countries, the Philippines does not have the military capacity to stand against China. In response, the Philippines decided to defend its claim using international law. The Philippines filed a case to have the South China Sea dispute heard in The Hague Tribunal. Despite China's 
immediate refusal, the hearings continued in 2015, which drew Japan and other ASEAN states to attend (Ministry of Foreign Affairs, 2014). As the PRC boycotted the hearings, the Philippines argued that the "nine-dotted" line claimed by the Chinese was illegitimate because it violated the United Nations Convention on the Law of the Sea principles on exclusive economic zones (Esmaquel, 2016). China rejected the appeal of the Philippines and stated, "unilateral initiation of the present arbitration by the Philippines will not change the history and fact of China's sovereignty over the South China Sea Islands and the adjacent waters" (Ministry of Foreign Affairs 2014). In 2016, The Hague Arbitration declared that the disputed areas of the South China Sea should be recognized under the jurisdiction of the Philippines. Despite the verdict, Beijing unilaterally refused to recognize the ruling (Esmaquel, 2016).

The United States attempted to arbitrate on behalf of the Philippines, but China refused to include the US in negotiations and insisted on a bilateral solution. Aquino continued to reject China's bilateral solution, prompting the worst moment for Philippine-China relations at the end of his term. These conflictual relations led to the construction of Chinese infrastructures, the artificial terraforming of islands, and other measures meant to harm the Philippine economy (Larson, 2015, p 1434). Specifically, China banned Philippine bananas and pineapples in the Chinese domestic market. Alongside the suspension on 28 exporters (Simeon, 2016), US\$33,000 worth of Philippine banana imports were destroyed in Shenzhen, harming the Philippine economy, as the second largest banana exporter in the world. Furthermore, led by the state-owned China Travel Service, the Chinese government banned its own tour companies from operating in the Philippines. This specific measure harmed the Philippine regional and local economies, which had been largely reliant on foreign cash flows in provincial economies. To make matters worse, China imposed a unilateral fishing ban on fisher folks in parts of the South China Sea (Esmaquel, 2016).

State investments-absence \& cancelation. Conflictual relations led to the absence and cancelation of Chinese state investments. Because of the tensions in the South China Sea and the highly controversial Chinese projects during Arroyo, the decision to allow high-profile Chinese investors became more difficult. Since the South China Sea popularized China's status as a bully in the Philippine media, it became increasingly difficult for politicians to openly endorse Chinese investments in the country, much less lobby for full foreign ownership. Regarding Chinese state investments, a member of the Liberal Party said "no one would endorse Chinese deals... maybe if you give them hundreds of millions [of pesos] in return." 27 He pointed out that during the Aquino administration, Philippine politicians in the media ceaselessly hammered on the South China Sea disputes for political gain, framing Chinese investments as a form of sabotage to elicit territorial concessions.

In addition, the potential for Chinese state investments faltered on another front. Aquino engaged in a vindictive witch-hunt that resulted in the political expulsion of Arroyo's allies from state positions. ${ }^{28}$ Because most politicians wanted to get on Aquino's good side, Chinese projects became popularly known as "sources of corruption" to the Philippine media or "political suicide" to many Philippine politicians. ${ }^{29}$ Along with the public denunciation of China, the limited allowable shares for foreign investors in most strategic Philippine sectors led to the more pronounced role of other non-Chinese investors (Camba forthcoming). Specifically, the United States, Japan and other countries from Europe and Southeast Asia even became more preferred investors and foreign partners benevolent in the eyes of the Philippine media.
Because of these political shifts, all the planned Chinese investments and the remaining turnover deals were canceled. In 2012, the Philippine government renegotiated the temporarily suspended North Rail project. Former Interior Secretary Manuel Roxas met with Chinese Foreign Affairs Vice Minister Fu Ying to lobby for replacing Sinomach with another company (Calica, 2016). After China rejected the suggestion, Roxas informed the Chinese government that the Philippines would likewise not pursue the project because of a Supreme Court (SC) ruling. ${ }^{30}$ After the meeting, Roxas and Ying decided to "cut clean" from the North Rail contract, leading to an agreement to repay the Chinese loans in four equal lump sums of US $\$ 46$ million over 2 years (Calica, 2016). After Roxas and Ying's meeting, the Philippines courted other foreign investors for the project. In 2014, the Japan International Cooperation Agency granted a US $\$ 2$ billion loan to the Philippine government to finish some segments of the rail while a number of Japanese companies also won the bid (Chanco, 2015). The Aquino government also decided to rely on Private and Public Partnership (PPP) to build the other segments of the railway (Schinabel, 2015).

Some people in the Philippine government were disappointed with the decision. The Arroyo administration already resettled thousands of informal settlers living along the railroad tracks. A consultant for various government projects said, "[Former] Vice President Noli De Castro successfully convinced the squatters to leave the area... and since the project did not push through, they [informal settlers] all came back!" 31 From an urban planning perspective, the Philippines' National Capital Region has a systemic problem of congestion underpinned by the intraregional migration, the rising number of cars, and the lack of space in the cities. The North Rail project could have alleviated this issue considerably and the Philippine government also paid millions of dollars for an unfinished project.

In addition, the new deal with Japan was worse in terms of cost: Japan's ODA for the rail was US\$60 million per $/ \mathrm{km}$ while a similar Chinese railway deal in Indonesia was only US\$35 million per $\mathrm{km}$ (Chanco, 2015). On the part of China, a Chinese government official noted, "there were skepticism towards the Philippines due to the lack of executive prerogative to pursue these deals." 32 In his view, unlike other Chinese ODA recipient countries, the political landscape and electoral cycle of the Philippines make long-term deals risky. In addition, the official pointed out, "the South China Sea issue became an annoying wrinkle... had the issue not occurred, Beijing would have been willing to renegotiate, give better terms, and even forgive the loan... just like what we did to Africa, Laos, and Cambodia." 33

To put this in perspective, there were over 20 deals negotiated and agreed upon during Arroyo. During Aquino, there was only one active Chinese state investment, and it was a project that passed during Arroyo. In late 2007, the State Grid Corporation of China (SGCC), a national SOE funded by the People's Bank of China, created a consortium with Calaca High Power Corporation and the Monte Oro Grid Resources Corporation to bid against San Miguel Energy, the Dutch TPG Aurora BV, and the Malaysian TNB Prai Bhd (Camba, 2016a). The bid won and the SGCC held a $40 \%$ stake in the National Grid Corporation of the Philippines.

Conflictual relations with China made the SGCC's operations a bit more complicated. In 2013, Roxas informed Beijing that there were security concerns about a foreign company's access to power grids. A Malacañang adviser from the Aquino administration emphasized these issues: "there were hypothetical concerns and worries over China's access to power in the Philippines that could lead to an invasion." ${ }^{34}$ This worry explains the Aquino government's decision not to renew the visa of 18 Chinese engineers of the company $(\mathrm{Xu}, 2016)$. Even though Chinese board members of 
the consortium were given visa extensions, the SGCC's access to power grids represented a genuine concern at the height of the South China Sea dispute. Though Aquino's people argued that the South China Sea issue had nothing to do with the visa decision, the Chinese government voiced out their concerns through official and unofficial channels (Esmaquel 2016).

As a whole, state investments suffered considerably because of conflictual relations. Apart from the potential investments, the North Rail, and the SGCC, other projects that were previously explored by and awarded to China were eventually handed to other foreign and national companies. Indeed, the 18 suspended agricultural projects between the Philippines and China were reviewed and eventually canceled by the Aquino administration (Alve, 2011). Afterwards, Japan, Malaysia, and Saudi Arabia were allowed to explore the agribusiness projects (Abu-Hussin, 2013). Filipino, Canadian, and Australian mining companies were given an even stronger role in the mining industry (Camba, 2015, p 298).

Private investments-rising inflows \& improved state capacity. Though conflictual relations continued, private investments rose during Aquino because of his government's strengthened administrative capacity. Host country sources indicate that private corporate investments were higher during Aquino to that of Arroyo despite the disputes in the South China Sea. Indeed, a total of US\$1.08 million entered the Philippines across 7 investment promotion agencies, surpassing Arroyo's US $\$ 554,469$ in 9 years. Comparing these absolute numbers proportionally, Arroyo received an average of $1.2 \%$ and Aquino got $2.5 \%$ of the overall amount of Chinese FDI in ASEAN.

Private companies, specifically those with modest amounts of money and largely financial autonomous from the Chinese state, were not discouraged from investing. Instead, the improvement of state capacity during Aquino's time kept the business environment strong and domestic political climate predictable. A Chinese investor in Philippine garments said, "Aquino is weird. [He's] so anti-Chinese and generates bad press. [But] he knows how to keep business separated from politics. His administration removed a lot of the permits and kept garment manufacturing free from greedy bureaucrats." ${ }^{35}$ In another export processing zone, a bag manufacturer said that during Aquino's time, there "were less resistance and tensions from the public, which made business easier in the provinces... officials facilitated rules and regulations better." ${ }^{36}$ The Philippine government was apathetic to the nationality of these private companies, and so long as political risk was kept at a minimum, Chinese private investments were willing to negotiate.

Examining the levels of legal-administrative, fiscal capacity, and infrastructural power explain the overall rise of private Chinese investments. Specifically, the Arroyo's administration's excessive rent-seeking practices stifled and limited state capacity. Aquino benefited from previous key legislations that Arroyo herself passed, such as the expanded value added tax, which led to an improvement of fiscal capacity. Aquino's administrations also passed several landmark bills that expanded their tax base. Of particular importance is the Sin Tax Reform Act, a bill designed to increase the Philippines' excise tax on alcohol and tobacco, which was passed despite lobbying from the sin industries (Official Gazette n.d.a). The law added US $\$ 1.10$ billion to the government budget in 2014. On top of these reforms, Aquino's Bureau of Internal Revenue Chief Kim Jacinto-Henares implemented BIR Master Plan for 2013-2016. With the goal of intensifying tax compliance and strengthening revenue collection in mind, Henares targeted the informal economy and deliberately filed cases to enforce the compliance of registered taxpayers. As a result of her work, key reforms on taxpayer service registration, audit, collection, enforcement, and revenue streaming were implemented. At some point, she even singled out big corporations accused of evading taxes (Official Gazette n.d.b). Due to the reforms, the BIR increased its tax collection by $12.2 \%$ in 2012 and $13.3 \%$ in 2013 (Rappler, 2015a). Comparing 2006 and 2013, the IMF Global Financial Stability Report indicated the improvement of auditing, reporting, and the efficiency of legal framework (IMF, 2016).

Legal-administrative capacity also improved. The Department of Finance and Central Bank of the Philippines had the space and power to craft monetary policy and limit discretionary departmental spending relative to their role during Arroyo (Official Gazette n.d.c). Since Aquino equipped these departments with greater relative autonomy, the Philippine government was able to expand revenue generation procedures and began to put into effect build-operate-transfer public private partnerships (BOTPPP) projects (Rappler, 2015b). As government budget surplus became more common, due to Aquino's financial policies, the BOT-PPP allowed the Philippine national corporations to borrow funds from capital markets to fund public infrastructure projects. While the BOT-PPP was conceptualized at the start of his regime, it only begun to make headway in 2012 due to some still burdensome government gridlock. Prudent state spending, a greater role for state bureaucrats, and a rapidly rising economy led to funding numerous but smaller infrastructural projects: Laguna Lakeshore Express Dike, regional prison facilities, and airports across the country. Though only 3 projects were completed, around 53 PPP projects were reviewed and 9 deals were at the beginning stages by the end of Aquino's term (Remitio, 2016).

Aquino also oversaw the Philippine Competition Law, which empowered the Department of Trade and Industry in broad areas of business licensing, retail, and certification (Schinabel, 2015). Such a law opened the space for domestic competition to govern market allocation, ensuring a predictable and healthy business climate. Indeed, the Philippines made a huge leap in the Ease of Doing Business category. At the end of Arroyo's term in 2010, the Philippines was ranked 141. During Aquino, the rank improved from 135 in 2010, 108 at the latter half of 2012 (Montecillo, 2013), and finally at 97 in 2014 (Mencurio, 2016). Jumping from 140-150 to 97-99 demonstrates the impact of the changes his administration made on the perception and the actual experience of businesses.

Aquino's reforms led to higher rates of economic growth. International credit ratings agencies, such as Japan Credit Rating Agency, Fitch, Moody's, and Standard and Poor's (S\&P), upgraded the investment grade status of the Philippines (Rappler, 2013). The IMD Competitiveness report indicated the rise of social cohesion from 3.44 in 2008 to 6.39 in 2013 onwards (IMD, 2016). Furthermore, the IMD World Competitiveness report upgraded the Philippines' image from 4.09 in 2008 to 6.16 in 2012 (IMD, 2016). GDP growth averaged 6.2\%, catapulting the Philippines as East-Southeast Asia's fastest growing economy (Schinabel, 2015). As the high-levels of growth came at the end of the commodity boom (1999-2011), which generated an economic slowdown in China, Brazil, and Indonesia in 2011, the pace of Philippine economic development at this time demonstrates its resilience amidst global economic slowdown.

Aquino's government was popularly elected and promoted key legislations that directly targeted social and economic needs. To bolster infrastructural power, numerous social legislations were enacted. One highlight in particular is the Domestic Workers Act, a piece of legislation designed to protect informal household workers (Official Gazette n.d.a). Aquino also supported the moratorium on mining projects due to numerous environmental 
and human rights controversies in the provinces. The boom of the service industry, which begun during Arroyo's final years, generated 7 million jobs across the country. Aquino also passed the National Health Insurance Executive Order, which has expanded the number of people covered under Philippine Health's coverage. Though still very limited, minimum wage also increased by US $\$ 3-4$ alongside conditional cash transfer projects for the poor (Official Gazette n.d.c). Because of these economic and social reforms, Aquino's popularity begun at +64 in the SWS survey and at $85 \%$ in Asia's trust survey. His popularity slowly dwindled due to the Disbursement Allocations Program, Yolanda habitation, the Mampasano clash. At the end of 2014, he only had a +29 in net satisfaction.

Despite his decreased popularity, class tensions were muted and the relevant dimensions of state capacity improved for the remainder of his presidency. Several sources accounted for this. First, in an interview with an official from the Department of Foreign Affairs, she noted, "numerous elites in the Liberal Party wanted to change the status quo, and there is now a need to strengthen government reforms in the face of a threat in the South China Sea." ${ }^{37}$ Due to trepidation, some elites were willing to limit rent-seeking and strengthen the state. Second, though there are good reasons to doubt these statements, interviewees identify Aquino's time as a period of normalcy for Philippine elite-led democracy. Given ample autonomy, Aquino's economic advisers along with their bureaucratic machinery were able to enact key reforms underpinned by a neoliberal logic. While his government did little to directly intervene in or fund large infrastructure projects, "doing little actually allowed the private sector do what it does best." ${ }^{38}$ And last, Aquino's government was legitimately elected and recognized by many. Though his regime suffered a decrease in net satisfaction by 2014 and the key factions of the political left intensified their opposition, his government was considered stable compared to that of Arroyo.

Illicit capital-the rise of mineral smuggling. While Chinese investments already occupied numerous ASM operations across the country, Aquino's time experienced the rise of Chinese ASM firms. There were many smaller Chinese mining companies that legally entered the Philippines during Arroyo's administration but, during Aquino, due to the simmering tensions in the South China Sea, regulatory weakness, and market opportunities, some Chinese mining companies resorted to investing in semi- or quasi-legal ASM mining firms. Ramon Peje, the secretary of the Department of Environment and Natural Resources (DENR), said, "the continuing high price of gold and the increasing number of small-scale mining areas, the decrease in gold purchases by the central bank clearly indicates that gold outputs are going to the black market and smuggling activities" (DENR, 2012).

As early as 2008, the DENR recommended to the Philippine government that stronger punitive measures be placed on the smuggling of mineral resources. While Aquino pursued the criminalization of Chinese ASM through observation of these measures, these were constrained and limited. This situation is particularly paradoxical because illegal small-scale mining funded by a variety of international funders takes place all over the country (Camba, 2015, p 297), but the Philippine state was especially swift in dealing out legal penalties to the Chinese. From the point of view of people in the Aquino administration, the illegal Chinese activities were an extension of their imperial activities in the South China Sea, ${ }^{39}$ one with roots in the insatiable hunger for the country's homegrown resources and juridically sanctioned territories.
In the town of Appari located in the province of Cagayan, the Philippine national police arrested 18 employees from Hua Xia Mining and Trading Corp (Carcamo, 2014). The company was allegedly involved in illegal black sand magnetite mining near the coast, which was intensifying soil erosion in the area. In 2010, the Philippine police arrested 100 Chinese nationals operating illegally in a chromite mine, and another ten were arrested in 2011 at another nearby mine (Carcamo, 2014). Aquino's administration arrested many Chinese nationals working in all kinds of economic sectors on expired visa permits from 2009 to 2014. Indeed, the media followed a similar narrative of linking mining to political tensions. In 2013 the Supreme Court issued a temporary environmental protection order against 94 small scale mines in the province of Zambales (Torres-Tupas, 2013). Instead of reporting the event as pro-environment or anti-mineral led development, it was celebrated as a nationalist move to protect Philippine minerals from Chinese smugglers (Torres-Tupas, 2013).

Despite Aquino's efforts, several alarming trends regarding the sale of gold to the Central Bank of the Philippines and the subsequent valuation in Hong Kong attest to the vibrant activity of mineral smuggling. Hong Kong data shows that gold from the Philippines amounted to $81,192 \mathrm{~kg}$ in 2011 (Francisco, 2012). However, data from the Bureau of Customs shows that only 3\% or roughly around $2430 \mathrm{~kg}$ were exported in that year (Francisco, 2012). As private individuals in the country were only allowed to sell gold to the Central Bank of the Philippines and could not engage in international trade (Reuters, 2013b), the Philippine government cannot explain this huge discrepancy, which could only attest to ASM and smuggling (Francisco, 2012).

Leo Jasareno, the Head of the Mines and Geosciences Bureau (MGB), said, "we have heard a lot of rumors about that- that it is being sold in Binondo [China town in Manila]" (Francisco, 2012). Echoing Jasareno's concerns, Walden Bello, a former congressman, said, "[he] received reports of the rise of illegal Chinese mining activities during Aquino, which was an irony because the increasing international conflict [between the Philippines and China]." ${ }^{\prime 80}$ Echoing similar sentiments, a Chinese investor said, "investors knew how sensitive the Aquino government is to strategic resources, which why they resorted to utilizing their local connections to extract resources." During my fieldwork in Bayombong in Nueva Vizcaya, a former local government official specifically noted that, "the national state does not have enough power to oversee legal firms and their activities, as well as police small-scale miners." ${ }^{\prime 1}$ Local government officials, thus, have the political power, know the geography, and garner the loyalty of the populace through jobs in the small-scale mines.

The failure to curb illicit capital during Aquino's time goes back to the low-levels of coercive capacity. While numerous international relations scholars discussed the attempts to strengthen the Philippine military's coercive capacity, these efforts were small and gradual improvements. The AFP Modernization Act, which was designed to upgrade internal and external defense capabilities, gave the AFP an additional US $\$ 1.8$ billion to acquire weapons, ships, and aircraft (Amer et al., 2015, p 15). With the additional budget, the Aquino administration in concert with the AFP enacted several plans to improve external defense and present a minimum deterrent against potential Chinese aggression. Specifically, they acquired the US Coast Guard Hamilton class cutter, examined 12 T-50 jets from South Korea, and initiated discussions on a missile defense system (De Castro, 2016c, p 119). Since Aquino's term, the US also begun to increase its military aid to the Philippines (Reuters, 2013a). From these standards, budget, military size, and sophistication improved but only to an insignificant degree. None of these changes directly affected the Philippines' capacity to police and 
regulate its maritime borders. For instance, the Philippine Navy received the least amount of aid, remains undermanned, and overworked. The AFP, reliant on "foot soldiers with minimum armored and aerial capacities," ${ }^{2}$ could not be bothered to police smugglers.

In sum, conflictual relations discouraged state investments but did not directly affect private investments due to the improvement across diverse types of state capacity. The South China Sea did not become an issue to the economically-focused agencies of the Philippine bureaucracy, though the exception applies to strategic sectors. Indeed, conflictual relations led to the unintended rise of illicit Chinese capital in Philippine ASM.

\section{Duterte's rapproachment with China (2016-onwards)}

Cooperative relations. Duterte's government yet again reversed the course of Philippine relations with China. He gave up the Philippines' arbitration victory, insisted on the usage of the South China Sea over the West Philippine Sea, and placated Beijing's worries. In a speech in Beijing, Duterte said, "I [Duterte] announce my separation from the United States... there's three of us [China, Russia, and the Philippines] against the world" (Calonzo et al., 2016). Though he vocally threatened to kick out the US troops and bases in the Philippines, Duterte's actual more balanced diplomatic approach in practice led to modest policy shifts. Though at times, Duterte asserted the rights of the Philippines in the South China Sea, his administration generally accommodates and appeases the Chinese. His method eventually yielded results. After Duterte's visit to China, Filipino fisher folks were eventually allowed back in the disputed areas. Furthermore, at the ASEAN dialog in August 2017, the Philippines proposed the Sino-Philippine joint energy cooperation, an offshoot of Arroyo's own Joint Maritime Seismic Undertaking. During the dialog, ASEAN members even expressed concerns over the strengthening of Philippine and Chinese ties (Huang, 2017). On its part, the PRC lifted a ban on Philippine banana exports in October 2016 (Simeon, 2016). China also committed to increasing agricultural imports from, and increasing tourist travels to, the Philippines (Ramirez, 2017).

Duterte's preference for a more balanced foreign policy, which led to the return of a cooperative Philippine-China relations, can be explained by two reasons. First, Duterte changed the previous administration's development strategy from maintaining a surplus on budgets underpinned by fiscal management to deficit spending in order to bolster infrastructures. Aquino's Public and Private Partnership capitalizes on the private sector's role to borrow foreign capital to pay for and at times manage the projects. In Aquino's strategy, the Philippine government becomes the vendor of projects, maintains a "hands off" approach to construction, and lets the private sector manage. Major Philippine capitalists bid and competed for entire or different segments of projects, leading to institutional backlog and structural infrastructural fragmentation. Though multiple roads, ports, and provincial airports were built during Aquino, the mass transport system and major types of infrastructures were neglected. As a result, class tensions-rising gap between the poor and rich, a narrow focus on GDP per capita growth, and the inability to deal with traffic (Camba, 2016a)-were redirected towards the PPP's "hand off approach" to state spending. In response, Duterte moved away from the sole focus on the PPP and opted to primarily use developmental aid to fund big infrastructure projects. Since China remains one of the biggest sources to fund major infrastructures (Camba, 2017), Duterte's administration opted to acquire Chinese aid.

Second, Duterte built his popularity on the initial promise to eradicate illegal drugs in the Philippines. Initially, he promised to eliminate illegal narcotics in the first 6 months of his term but eventually took a more realistic stance. His administration was heavily criticized by leaders of the West. Before Donald Trump's term, Barack Obama (2009-2017) criticized Duterte for his terrible human rights record. In response, Duterte fired back at Obama and the US more broadly, accusing both of previously unatoned for colonial massacres and exploitation. Duterte was also subsequently criticized by the European Union and other human rights organizations across the world. An informal adviser to the Duterte administration argued that because of the lack of initial support from the US and other traditional allies of the Philippines, Duterte appealed to China to back his drug campaign. ${ }^{43}$ Similarly, Heydarian noted that China was the first country to offer unconditional support to Duterte's drug war (Heydarian, 2017). Indeed, in Duterte's war on drugs, a US senator blocked a shipment of arms to the Philippine National Police (Zengerle, 2017). In response, Duterte acquired arms from China, which were eventually handed over to the Philippine National Police. Duterte's "War on Drugs" uses Chinese bullets and guns to kill thousands of alleged Filipino drug pushers. ${ }^{44}$ More recently, China has also committed to fund rehabilitation camps for former drug addicts.

State investments-resurgence, negotiations, and possible realization. The reemergence of cooperative relations led the resurgence of Chinese state investments, culminating in Duterte's recent visit to Beijing and agreements worth billions (Ranada, 2016). As many other observers pointed out, Philippine and Chinese relations made a complete reversal: passed 24 agreements during the state visit to China; signed memorandum of agreements with companies worth US\$15 billion; and US\$9 billion in loans (Ranada, 2016). While cooperative relations may provide the much needed financing for infrastructure projects, Kenneth Cardenas (2017) points out that these recent Chinese companies have partnered up with questionable Philippine corporations, which signal the high probability of project failures and rentseeking practices. While the Chinese and Philippine governments seem to be continuing what the Arroyo government started in 2003, my paper points out key differences between the administrations. Not only did Duterte inherit Aquino's economic gains and strengthened institutions, but he also has stronger infrastructural power at his disposal to eventually implement and realize these large state investments. While his SWS net satisfaction follows a similar trend to Aquino's starting years (around +64 ), his Asia's Trust rating score is at 92\% (Social Weather Stations, 2017). Though cooperative relation is a prerequisite for the negotiations of these kinds of investments, the presence of a strong infrastructural power, which Arroyo severely lacked, is what could lead to the actual realization of FDI projects. A partial list of the potential deals can be seen in Table 3:

While there is a lot of tempered enthuasism regarding Chinese state investments, several projects appear to be in the beginning stages of negotiations and at the start of actual implementation. In an interview with an investor in the garment factory, he said, "with his [Duterte's] gesture towards China, it looks like big players might arrive soon." ${ }^{4}$ The PRC is back in the strategic sectors of transportation, energy, and infrastructure. In October 2017, China and the Philippines agreed on a US\$9 billion loan for Philippine National Railway's Bicol Express, which would connect the Southern Luzon provinces to Metro Manila by rail (Escandor, 2017). In addition, China has been targeted to build the Mindanao Railway Project (Colina, 2017). Alfredo Yao, a Philippine economic elite, decided to partner with Energy China to construct a US\$2 billion coal-fired power plant in Luzon (Dumlao-Abadilla, 2016). These dynamics are not only limited to 
Table 3 Duterte's partial list of China Deals

\begin{tabular}{|c|c|c|c|}
\hline Project & Chinese Company & Philippine Company & Worth \\
\hline Cabling Manufacturing Facilities & Suli Group LTD & MVP Global Infrastructure & $\$ 3$ billion \\
\hline Infrastructure Investment & China Railway Corporations (CREC) & MVP Global Infrastructure Group & $\$ 2$ billion \\
\hline 300 MW Pulangui-5 Hydro Project & Power China Sino Hydro & $\begin{array}{l}\text { Greenergy Development } \\
\text { Corporations }\end{array}$ & $\$ 1$ billion \\
\hline Davao Coastline Port Development & China Harbor Engineering Co. Ltd. (CHEC) & $\begin{array}{l}\text { Mega Harbor Port and Development, } \\
\text { INC }\end{array}$ & $\$ 780$ million \\
\hline Steel Plant & Baiyin International Investment & Global Ferronickel & $\$ 500$ million \\
\hline Manggahan Floodway Bridges & Sino Hydro & Zonar Construct & $\$ 600$ million \\
\hline Mindanao River Basin Flood Control Project & Sino Hydro & One White Beach Land Development & $\$ 32$ million \\
\hline Manufacturing Facility & Zhuhai Granton Bus & Coach Company & $\$ 300$ million \\
\hline Steel Manufacturing Plant & SIIC Shanghai International Trade Hong Ong & $\begin{array}{l}\text { Manage Resources Trade } \\
\text { Corporation }\end{array}$ & $\$ 200$ million \\
\hline $\begin{array}{l}\text { Hybrid Rice for Two Million Hectares of Rice } \\
\text { Field }\end{array}$ & Jiangsu Hongqi Seed Co. Ltd. & SL Agritech Group & $\$ 160$ million \\
\hline Harbor Center Reclamation Project & China Harbor Engineering Co. Ltd (CHEC) & R-II Builders, Inc. & $\$ 148$ million \\
\hline EDSA Bus Program & $\begin{array}{l}\text { Yangtse Motor Group Ltd. And Minmetals } \\
\text { International HK }\end{array}$ & Philippine State Group of Companies & $\$ 100$ million \\
\hline $\begin{array}{l}\text { Renewable Energy, Major Infrastructure, and } \\
\text { Real Estate }\end{array}$ & China CAMCE Engineering Co. LTD. & Colombus Capitana & $\$ 100$ million \\
\hline Banana plantation & $\begin{array}{l}\text { Shanghai Xinwo Agriculture Development Co. } \\
\text { Ltd }\end{array}$ & AVLP Asia Pacific Conglomerate & $\$ 100$ million \\
\hline
\end{tabular}

infrastructure and energy, but also numerous other projects in dam construction, roads, and bridges across the country. A highranking corporate representative from ZTE argued that major Chinese state corporations had little-to-no interaction with the Philippine government during Aquino. But "now, there is a lot of [Chinese and Philippine government engagements] but during Aquino, it was just silent and we could not compete nor plan for government contracts." ${ }^{46}$

Private investments-a boom. Private Chinese investments have boomed since Duterte's victory. Numerous Chinese companies begun to invest in and partner with local Philippine businessmen in real estate, tourism, retail, and even services. ${ }^{47}$ Due to the high supply and continuous buildup of condominium units, Chinese businesses and citizens begun to purchase condominium units in Metro Manila, Cebu, and Tagaytay. An official from Makati City said that the number of Chinese citizens who have applied for residential permits increased remarkably at the end of $2016 .{ }^{48}$ Chinese tourist companies began eyeing the Philippines as a new destination for tourism. Beijing Tourist Group and Asia Landmark Tours and Travels said that Duterte's cooperative relation with China was the sole reason for restarting operations in the Philippines. ${ }^{49}$ By August 2017, Chinese tourists became the third largest source for the entire country, rising by $33.4 \%$ since Duterte took power. The uptick in tourism can also be seen in the negotiations for multiple agreements between Philippine and Chinese companies. In an interview with a Philippine lawyer, she said that her firm began mediating a deal between a prominent Chinese airline and the Philippine government. ${ }^{50}$ Indeed, this specific airline seeks to open lines from Chinese cities to various parts of the Philippines: Boracay, Cebu, Palawan, and many others. Furthermore, top law firms across the Philippines even started marketing their services to China and hiring mandarinspeaking Filipino law school graduates. ${ }^{51}$

In the words of a major Philippine economic elite, Duterte "normalized the abnormal situation during the Aquino administration... he let the Chinese feel welcome instead of being apathetic [at best] about it." ${ }^{\text {2 }}$ The same elite said that the rise of private Chinese investments occurred during Aquino in spite of his anti-Chinese and porous national sentiments and that those investment "could have been higher [had Aquino been cooperative]...think about how many jobs and lives he could have changed." ${ }^{33}$ In sum, the combination of an inherited state capacity across relevant dimensions during Aquino and cooperative relations with Beijing explain the rise of private Chinese FDI. $^{54}$

Illicit capital-deteriorating and dwindling. Illicit capital appears to have dwindled down during Duterte. Gina Lopez, the former Secretary of the Department of Environment and Natural Resources, previously closed-down numerous large-scale and small-scale mines. ${ }^{55}$ Though Duterte criticized the mining sector, Lopez' appointment was eventually rejected, affirming the administration's commitment to a mineral-driven economic strategy. With the departure of Lopez, a likely possibility is that cooperative relations will make Chinese investments in the mining sector less risky. Like Arroyo's administration, Duterte's term may see an increase in Chinese mining companies. The key difference lies in Duterte's popularity and infrastructural power, which could mean limited political opposition and social movement mobilization against such proposed projects. As a result, bigger Chinese mining companies with more technology, liquidity, and experience may emerge in the Philippines during Duterte's term. Should these possibilities occur, ASM may decrease even more as a result of new legal avenues for Chinese mining investors. Some Chinese-funded ASM firms will likely continue, and the Philippine armed forces will be unable to stop most of these operations due to their weak coercive capacity despite recent improvements. These empirics partly confirm the argument that conflictual relations and weak coercive capacity can lead to the rise of illicit capital, but cooperative relations can limit the motivation of illegal firms due to the available legal avenue.

\section{Discussion}

I summarize my findings in Table 4. During Arroyo, cooperative relations led to negotiation of Chinese state investments. Weak infrastructural power hindered the realization of these state 
Table 4 Summary of key findings

\begin{tabular}{|c|c|c|c|}
\hline Cases & State Investments & Private Investments & Illicit Capital \\
\hline $\begin{array}{l}\text { Cooperative Relations I Weak state capacities: fiscal, } \\
\text { administrative-legal, coercive, infrastructural power } \\
\text { (Gloria Macapagal Arroyo, 2001-2010) }\end{array}$ & $\begin{array}{l}\text { Significant Rise (but not } \\
\text { realized) }\end{array}$ & $\begin{array}{l}\text { Rise (or stagnant relative to huge } \\
\text { expectations) }\end{array}$ & $\begin{array}{l}\text { Decline (or stagnant due } \\
\text { to available legal } \\
\text { avenues) }\end{array}$ \\
\hline $\begin{array}{l}\text { Cooperative Relations I Inherited state capacity but } \\
\text { changes can still occur (Rodrigo Duterte, 2016- } \\
\text { onwards) }\end{array}$ & $\begin{array}{l}\text { Significant Rise (appears to be, } \\
\text { at least on-going negotiations) }\end{array}$ & $\begin{array}{l}\text { Significant Rise (tempered } \\
\text { enthusiasm for the private } \\
\text { Chinese investments) }\end{array}$ & $\begin{array}{l}\text { Decline (shift to legal } \\
\text { avenues) }\end{array}$ \\
\hline
\end{tabular}

investments while weak state legal-administrative and fiscal capacity challenged and hindered the arrival of new, competitive private companies. Illicit capital was limited because of the available legal options to the Chinese mining companies. During Aquino, the conflictual relations limited Chinese state investments. Simultaneously, an influx of private investments occurred due to the improvement of fiscal-administrative and legal capacity. However, illicit capital grew because of the greater national scrutiny on Chinese companies in key strategic sectors and the military's inability to police Philippine borders. During Duterte, the return to cooperative relations alongside the inherited improved capacity from Aquino's time will most likely lead to the rise of both state and private investments. Illicit capital has reportedly gone down due to the initial scrutiny of the government and the new available legal options.

I make two theoretical contributions. First, most of the literature groups Chinese FDI in a single, coherent whole and makes inferences from this broad category. In response, I disaggregate Chinese FDI into three different strands: state investments, private investments, and illicit capital. Afterwards, I showed how the configuration of inter-state relations and types state capacity shape the rise or fall of these FDIs. In showing the different responses of various types of Chinese FDI to the inter-state relations and state capacities in the host country, it modifies the assumption in the literature that weak state capacity and poor institutions draw in higher yields of Chinese FDI. This finding demonstrates the protean nature of Chinese FDI: it is able to adapt to different political conditions and historical circumstances. The disaggregation also affirms some ethnographic work in Africa and Southeast Asia conducted to show the difference between Western and Chinese capital (Camba forthcoming; Lee, 2014). My finding is also consistent with the recent ethnographic literature on Chinese outward FDI that stresses the importance of people, places, and ideas (Nyíri and Tan, 2016).

One key problem of the quantitative literature is that datasets on Chinese FDI tend to have an overconcentration of state investments, usually upwards of billions of dollars. Since state investments primarily follow political considerations and invest in places with weak institutions, these datasets would not take into account the logic of private investments. Smaller private companies could only muster a few millions, thereby creating biased results in favor of SOEs and state investments. As the quantitative literature relies on datasets which could only capture whether investments entered the country, numerous and sophisticated modeling miss the different circumstances of various projects. In addition, most Chinese FDI can also be located in countries with strong institutions, which could be explained by the dataset's selective focus on specific time periods and countries in the developing world (UNCTAD, 2015).

Second, this paper links the IR literature on inter-state relations and the comparative politics research on state capacity. From the beginning, I showed that the types of state capacity alongside the configuration of inter-state relations matter in shaping the rise or fall of Chinese FDI. While agreements on state investments depend on cooperative inter-state relations, the degree of the state's infrastructural power shapes societal resistance and political opposition to these ventures. While the type of inter-state relations influences the legal or illegal routes of illicit capital, the degree of coercive capacity constrains the success or failure of these operations. Legal-administrative and fiscal seem to matter the most when it comes to private investments. While the existing works focus on measuring, quantifying, and analyzing various types of state capacity in different historical circumstances, my work brings inter-state relations back into the picture, which has largely omitted as a contributory factor. Furthermore, I demonstrated how state capacity remains historically contingent, evolving from one administration to another, embedded in the structure of social relations during the different times. As analyzing these conditions must be historically and globally situated, the strengthening or weakening of state capacity for many developing world states may be contingent in today's slowdown of neoliberalism, frustrations on elitism, and reemergence of "populism."

Received: 15 February 2017 Accepted: 26 October 2017 Published online: 05 December 2017

\section{Notes}

1 These numerous works have arrived at similar conclusions using slightly different but related concepts. That is, Chinese FDI is highly correlated with high corruption, poor institutions, and more political risks. For the paper, I use "weak state capacity" to refer to the similar outcomes of these other concepts.

2 As a portion of the Pacific Ocean, which encompasses the Malacca Straits to the Straits of Taiwan, the South China Sea encompasses over 250 islands subdivided in five parts-Paracel, Spratlys, Pratas, Scarborough Shoals, and Macclesfield Bank. The South China Sea remains significant because of trade, resources, and security. For a summary, see Kaplan (2014).

3 Qualitative studies focus on the impact of Chinese FDI. Using semi-structured interviews, Daniel O'Neill finds that Chinese outward FDI in Cambodia and Kazakhstan have increased due the People's Republic of China's (PRC) concern for geopolitics and energy supplies (O’Neill, 2014a, b). In much of Deborah Bräutigam's work in Sub-Saharan Africa, she demonstrates the PRC's developmental impact across a wide variety of sectors (Bräutigam, 2009, 2011).

4 Improvement in state capacity can be "perceived" and "real." The difference of the two is outside the scope of the paper since the interest is more of the general improvement instead of the difference between perceptions and actual outcomes.

5 The statistics do conflate the PRC and Hong Kong SAR. Taiwanese, Singaporean, Southeast Asian Chinese investments are named after their country of origin.

6 Instead of success or failure, the paper uses more subjective measures. The six categorical measures are: significant rise, moderate rise, rise, significant decline, moderate decline, and decline. Though none of these will be numerically accurate, these categories can tie in the qualitative assessments of, and the quantitative data on, investments.

7 Using aggregate statistics from the host country or Chinese sources, it is possible to capture joint ventures by PRC entities with host country actors. If PRC Chinese joins 
up with a Filipino-Chinese businessperson to form a company, the data will only add amount of money from PRC citizen to the overall amount of Chinese FDI. The Filipino-Chinese share will be considered "domestic."

8 To calculate this, I used Chinese FDI in Southeast Asia as the dividend and Chinese FDI in the Philippines as the divisor. I looked at the amount from 2005 to 2016.

9 Due to the politically sensitive nature of the topic, I anonymized most of my interviewees. However, I will name those who gave me permission to reveal their identities

10 While the CGIT suffers from the lack of verifiability due to its reliance on purchased market data, it has the advantage of tracking PRC investments that went to Hong Kong.

11 The main drawback is that outside researchers cannot check the MOFCOM data from various Chinese embassies and companies around the world. Numerous Chinese academics also doubt the data's veracity.

12 Data in Fig. 3 has been taken from various Investment Promotion Agencies and the Philippine Statistical Office. Using the documents from these agencies, I compared, synthesized, and reconstructed the data. The weakness of host country data is that it's often difficult to maneuver the bureaucratic intricacies of host countries. But in my view, at least in the Philippine case, host country data is the most reliable due to the deposit records in the banks. It is also the closest to the "actual investment."

13 I anonymized both towns and provinces due to present concerns in the Philippine mining sector.

14 Interview with a former official of the Office of the President during the Arroyo government, Makati City, 29 July 2017.

15 Before Estrada went to jail, the elites around him tried to organize a counter "People Power."

16 Interview with Chinese investor, Subic Bay Metropolitan Authority, Subic City, 10 August 2017.

17 Ibid.

18 Ibid.

19 Interview with Chinese investor, Subic Bay Metropolitan Authority, Subic City, 10 August 2017.

20 Interview with Chinese investor, Cagayan Economic Zone Authority, Cagayan City, 1 August 2017.

21 Interview with a former official of the Office of the President during the Arroyo government, Makati City, 29 July 2017.

22 Interviews with numerous civil society leaders in 2014 verifies affirms this view.

23 Interview with a military intelligence analyst, Makati City, 18 August 2017.

24 Interview with Richard Heydarian, Quezon City, 3 August 2017.

25 Interview with an adviser to the Aquino administration, Mandaluyong City, 2 August 2017.

26 The survey ship was allegedly exploring for minerals and oil. Heydarian notes that Aquino was still trying to reconcile relations with China while simultaneously defending the Philippines' claim in the South China Sea. The more nationalist stance towards the South China Sea eventually became the dominant track of the administration in late 2013.

27 Interview with a member of the Liberal Party, Mandaluyong City, 5 August 2017.

28 While there are many known examples, the impeachment against former Supreme Court Judge Renato Corona is the most prominent.

29 Ibid.

30 During Arroyo, the SC argued that Arroyo's government and North Rail Corp. violated the Procurement Law of the Philippine constitution, which made the deal unconstitutional.

31 Interview with a consultant or "broker," Mandaluyong City, 5 August 2017.

32 Interview with an official from a Chinese state institution, Summer 2017. I anonymized the interview date and location for security reasons.

33 Ibid.

34 Interview with an adviser to the Aquino administration, Mandaluyong City, 2 August 2017.

35 Interview with Chinese investor, Subic Metropolitan Bay Authority, Subic City, 10 August 2017

36 Interview with Chinese investor, Authority of Freeport of Bataan, Bataan City, 13 August 2017

37 Interview with a member of the Liberal Party, Mandaluyong City, 5 August 2017. 38 Interview with Raul Fabella, UP Professor Emeritus, Quezon City, 2 August 2017.

39 Interview with a member of the Liberal Party, Mandaluyong City, 5 August 2017.

40 Interview with Walden Bello, Quezon City, 18 August 2017.

41 Interview with former local government unit official, Bayombong, Nueva Vizcaya, 26 June 2014.

42 Interview with a military intelligence analyst, Makati City, 18 August 2017.

43 Interview with informal adviser to the Duterte Government, Manila, 16 August 2017.

44 Interview with a military intelligence analyst, Makati City, 18 August 2017.

45 Interview with Chinese investor, Authority of Freeport of Bataan, Bataan City, 13 August 2017.

46 Interview with an official from ZTE Corporation, Makati City, 15 August 2017.

47 Interview with Chinese investor, Singapore, 25 July 2017.

48 Interview with Makati city hall official, Makati City, 1 August 2017.
49 Interview with Chinese investor, Singapore, 25 July 2017.

50 Interview with a law firm partner, 7 August 2017.

51 Ibid.

52 Interview with a major Filipino economic elite, Makati City, 19 August 2017.

53 Ibid.

54 At the time of the article's writing, Duterte still has the same score in EOB and IMD ratings.

55 Interview with Chinese investor, Cagayan Economic Zone Authority, Cagayan City, 1 August 2017.

\section{References}

Abu-Hussin M (2013) Gulf Arab Foreign Direct Investment (FDI): ASEAN Targets of Opportunity. Middle East Institute

Alesina A, Dollar D (2000) Who gives foreign aid to whom and why? J Econ Growth 5(1):33-63

Alve K (2011) Gov't reviewing big land-lease deals. Inquirer, September 2011 http://newsinfo.inquirer.net/65623/gov\%E2\%80\%99t-reviewing-big-landlease-deals

Amer R, Batongbacal J, Beckman R, Chalermpalanupap T, Dang TN, Dung PL, Hong N, Li J, Nguyen LN, Poling G and Rothwell DR (2015) Power, law, and maritime order in the South China Sea. Lexington Books

Arase D (1995) Buying power: the political economy of Japan's foreign aid. Lynne Rienner Publishers

Bandelj N (2008) From communists to foreign capitalists: The social foundations of foreign direct investment in postsocialist Europe. Princeton University Press

Bandelj N (2009) The Global Economy as Instituted Process: The Case of Central and Eastern Europe. Am Sociol Rev 74(1):128-149

Bebbington A, Bury J (2013) Subterranean struggles: New dynamics of mining, oil, and gas in Latin America. University of Texas Press, Austin

Bosshard P (2010) China's overseas dam builders: From Rogue players to responsible actors. Asia Pacific J Japan Focus 17(2):26

Bower E (2010) The JMSU: a tale of bilateralism and secrecy in the South China Sea, Southeast Asia from the corner of 18th \& K Streets, 27 July. Center for Strategic and International Studies

Bradsher K (2014) Philippine leader sounds alarm on China. New York Times, 4

Bräutigam D (2009) The dragon's gift: the real story of China in Africa. Oxford University Press

Bräutigam D (2011) Aid "with Chinese characteristics": Chinese foreign aid and development finance meet the OECD-DAC aid regime. J Int Dev 23(5):752-764

Buszynski L (2012) The South China Sea: oil, maritime claims, and US-China strategic rivalry. Wash Q 35(2):139-156

Calica A (2016) Phl, China drop North Rail. Philippine Star, 26 September. http:// www.philstar.com/headlines/2012/09/26/852997/phl-china-drop-north-rail

Calonzo A et al. (2016) Duterte Bids U.S. Goodbye with Embrace of China and Russia. Bloomberg News. https://www.bloomberg.com/news/articles/2016 10-20/china-hails-deal-with-duterte-to-restart-south-china-sea-talks

Calvo GA, Leiderman L, Reinhart CM (1993) Capital inflows and real exchange rate appreciation in Latin America: the role of external factors. IMF Staff Pap 40(1):108-151

Camba AA (2015) From colonialism to neoliberalism: Critical reflections on Philippine mining in the long twentieth century. Extract Indust Soc 2 (2):287-301

Camba AA (2016a) Contentious capital: The political economy of Chinese investments in the Philippines. Albetro Del Rosario Institute (ADRI) for Strategic and International StudPlease check whether the Journal name in reference Camba (2016a) is ok.ies 9(11):1-16

Camba AA (2016b) Philippine mining capitalism: The changing terrains of struggle in the neoliberal mining regime. Austrian J South East Asian Stud 9 (1):69-86

Camba AA Forthcoming. The direction, patterns, and practices of Chinese investments in Philippine mining. In: Morris-Jung J (ed) In China's backyard: policies and politics of China's resource engagements in Southeast Asia, Institute of Southeast Asian Studies, Singapore

Camba AA (2017) China's port acquisitions in Sri Lanka and Djibouti: Lessons on Chinese developmental financing for the Philippines, Stratbase-Alberto Del Rosario Institute (ADRI) for Strategic and International Studies, Second Quarter SPARK

Capling A, Ravenhill J (2011) Multilateralising regionalism: what role for the transpacific partnership agreement? Pacific Rev 24(5):553-575. by Alecks P. Pabico

Carcamo D (2014) 14 Chinese nabbed in camsur illegal mining site, Philippine Star, 4 February 2014. http://www.philstar.com/nation/2014/02/07/1287722/ 14-chinese-nabbed-camsur-illegal-mining-site

Cardenas K (2017) Duterte China deals, dissected. Philippine center for investigative journalism, 8 May. http://pcij.org/stories/dutertes-china-dealsdissected/ 
Chanco B (2015) NorthRail gets new life from Japan. Philippine Star, 25 November. http://www.philstar.com/business/2015/11/25/1525529/northrailgets-new-life-japan

Cheung YW, Qian X (2009) Empirics of China's outward direct investment. Pacific Econ Rev 14(3):312-341

Colina IV, A (2017). Alvarez: Phase 1 of Mindanao railway to start early next year. Mindanews, 17 June. http://www.mindanews.com/top-stories/2017/06/ alvarez-phase-1-of-mindanao-railway-to-start-early-next-year/

Culem CG (1988) The locational determinants of direct investments among industrialized countries. Eur Econ Rev 32(4):885-904

Davao Today (2006) Big Chinese mining firms set eyes on Mindanao. http:// davaotoday.com/main/environment/big-chinese-mining-firms-set-eyes-onmindanao/

De Castro RC (2009) The US-Philippine alliance: An evolving hedge against an emerging China challenge. Contemp Southeast Asia: 31(3):399-423

De Castro RC (2014) The 21st century Philippine-US Enhanced Defense Cooperation Agreement (EDCA): The Philippines' policy in facilitating the Obama administration's strategic pivot to Asia. Korean J Defense Anal 26 (4):427-446

De Castro RC (2016a) Facing up to China's realpolitik approach in the South China Sea dispute: The case of the 2012 Scarborough Shoal stand-off and its aftermath. J Asian Security Int Aff 3(2):157-182

De Castro RC (2016b) Twenty-first century Philippines' policy toward an emergent China: from equi-balancing to strategic balancing. Asian Polit Policy 8 (2):305-328

De Castro RC (2016c) The Philippines discovers its maritime domain: The aquino administration's shift in strategic focus from internal to maritime security.". Asian Secur 12(2):111-131

De la Cruz R (2010) The new conquistadores and one very willing colony: a discussion of global land grabbing and the Philippine experiences." ARnow! Working Paper

DENR (2012) Gold production declines, Paje cites smuggling, 20 August

Duanmu, J (2012) Firm heterogeneity and location choice of Chinese Multinational Enterprises (MNEs). J World Bus 47(1):64-72

Dumlao-Abadilla D (2016) Yaos, energy China team up for \$2-B power project, Inquirer. 24 October. http://business.inquirer.net/217295/yaos-energy-chinateam-up-for-2-b-power-project

Dunning JH (1998) Location and the multinational enterprise: a neglected factor? J Int Bus Stud 29(1): 45-66

Dunning JH (2003) Determinants of foreign direct investment: globalizationinduced changes and the role of policies. In annual World Bank conference on development economics, Europe, toward pro-poor policies aid, institutions, and globalization. Edited by Bertil Tungodden, Nicholas Stern, and Ivar Kolstad (p. 279-290)

Escandor Jr. J (2017) P175-B development aid from China to revive PNR's Bicol Express. Inquirer, 21 October $21 \mathrm{http} / / /$ business.inquirer.net/239005/pnrbicol-express-reconstruction-china-loan

Esmaquel P (2015) China defends experts in Philippine power firm. Rappler, 4 March https://www.rappler.com/nation/85709-china-philippines-powerfirm-ngcp

Esmaquel P (2016) Aquino: The president who brought China to court. Rappler, 29 June. https://www.rappler.com/nation/137939-president-aquino-westphilippine-sea-china-dispute

Francisco, R (2012) Special report: Philippines' black market is China's golden connection, Reuters. http://www.reuters.com/article/2012/08/23/usphilippines-gold-idUSBRE87M02120120823

Gilpin, R (2016) The political economy of international relations. Princeton University Press

Hanson JK, Sigman R (2013) Leviathan's latent dimensions: Measuring state capacity for comparative political research

Harvey D (2003) The new imperialism. Oxford University Press, USA

Hentschel T, Hruschka F, Priester M (2002) Global report on artisanal and smallscale mining. Report commissioned by the mining, minerals and sustainable development of the international institute for environment and development. http://www. iied. org/mmsd/mmsd_pdfs/asm_global_report_draft_jan02.pdf on, 20(08), 2008

Heydarian RJ (2014) South China Sea legal battle hots up. Straits Times, 18 December. http://www.straitstimes.com/opinion/south-china-sea-legal-battle-hots-up

Heydarian RJ (2017) Manila's war on drugs is helping to build bridges between China and Philippines. South China Morning Post, 1 October. http://www. scmp.com/news/china/diplomacy-defence/article/2113357/manilas-wardrugs-helping-build-bridges-between-china

Hirschman A (1980) National power and the structure of foreign trade, vol 105. Univ of California Press

Human Rights Watch (2015) What ... if Something Went Wrong?" Hazardous Child Labor in Small-Scale Gold Mining in the Philippines. https://www. hrw.org/report/2015/09/29/what-if-something-went-wrong/hazardous-childlabor-small-scale-gold-mining
Huth PK (1998) Major power intervention in international crises, 1918-1988. J Confl Resolut 42(6):744-770

Huang K (2017) Duterte's joint energy plan for South China Sea may test Asean's unity. South China Morning Post, 28 July. http://www.scmp.com/news/ china/diplomacy-defence/article/2104546/dutertes-joint-energy-plan-southchina-sea-may-test

Hung $\mathrm{H}$ (2008) Rise of China and the global overaccumulation crisis. Rev Int Political Econ 15(2):149-179

Hung H (2015) The China Boom. Colombia University Press, New York

Hutchcroft P (2008) The Arroyo Imbroglio in the Philippines. J Democr 19 (1):141-155

Ibon Foundation (2010) Dark legacies: The economy under Arroyo. Features

IMD (2016) IMD world talent report 2016. IMD World Competitiveness Center

IMF (2016) Global financial stability report, April 2016. International Monetary Fund

Jensen N, Biglaiser G, Li Q (2012). Politics and foreign direct investment. University of Michigan Press

Kaplan RD (2014) Asia's cauldron: The South China Sea and the end of a stable pacific. Random House

Kang SJ, Lee H, Park B (2011) Does Korea follow Japan in foreign aid? Relationships between aid and foreign investment. Japan World Econ 23(1):19-27

Kang Y, Jiang F (2012) FDI location choice of Chinese multinationals in East and Southeast Asia: Traditional economic factors and institutional perspective. J World Bus 47(1):45-53

Kisangani EF, Pickering J (2014) Rebels, rivals, and post-colonial state-building: Identifying bellicist influences on state extractive capability. Int Stud Quarter 58(1):187-198

Kolstad I, Wiig A (2012) What determines Chinese outward FDI? J World Bus 47(1):26-34

Komatsuzaki T (2016) Improving public infrastructure in the Philippines

Landingin R, (2008) The perils and pitfalls of aid. ODA surge sparks scandals for Arroyo, debt woes for RP. Philippine Center for Investigative Journalism, 11 Feb

Landingin R, (2010) Chinese foreign aid goes offtrack in the Philippines. SouthSouth cooperation: A challenge to the aid system?

Larson C (2015) China's island building is destroying reefs. Science 349(6255):1434

Larsson T (2013) The strong and the weak: Ups and downs of state capacity in Southeast Asia. Asian Polit Policy 5(3):337-358

Lee CK (2009) Raw encounters: Chinese managers, African workers and the politics of casualization in Africa's Chinese enclaves. China Q 199:647-666

Lee CK (2014) The spectre of global China. New Left Rev 89:29-65

Li Q (2008) Foreign direct investment and interstate military conflict. J Int Aff 53-66

Lunn J (1983) Determinants of US direct investment in the EEC: Revisited again. Eur Econ Rev 21(3):391-393

Mann M (1984) The autonomous power of the state: its origins, mechanisms and results. Eur J Soc 25(02):185-213

Mencurio R (2016) Philippines boost global ranking in ease of doing business. Philippine Star, 27 October. http://www.philstar.com/business/2016/10/27/ 1637573/philippines-boosts-global-ranking-ease-doing-business

Ministry of Foreign Affairs of the People's Republic of China (2014) Position paper of the government of the people's Republic of China on matter of jurisdiction in the South China Sea arbitration initiated by the Republic of the Philippines, People's Republic of China. http://www.fmprc.gov.cn/mfa_eng/ zxxx 662805/t1217147.shtml. Accessed 8 Dec 2014

Montecillo P (2013) Ph world's most-improved in WB ease of doing business ranking. Philippine Inquirer, 29 October. http://business.inquirer.net/149815/ ph-worlds-most-improved-in-wb-ease-of-doing-business-ranking

Moravcsik A (2013) The choice forEurope: social purpose and state power from Messina to Maastricht. Routledge

Nigh D (1986) Political events and the foreign direct investment decision: An empirical examination. Manage Decis Econ 7(2):99-106

Nyíri P and Tan D (eds) (2016) Chinese encounters in Southeast Asia: How people, money, and ideas from China are changing a region. University of Washington Press

Olibe KO, Crumbley CL (1997) Determinants of US private foreign direct investments in OPEC nations: from public and non-public policy perspectives. J Pub Budget Account Financ Manage 9(2):331

O'Neill DC (2014a) Risky business: The political economy of Chinese investment in Kazakhstan. J Eurasian Stud 5(2):145-156

O'neill D (2014b) Playing risk: Chinese foreign direct investment in Cambodia. Contemporary Southeast Asia. J Int Strateg Aff 36(2):173-205

Official Gazette (n.d.a) Economic development

Official Gazette (n.d.b) the Philippines under the Aquino administration

Official Gazette (n.d.c) Human development and poverty reduction

Pabico A (2008) Gloria's inglorious record: Biggest debtor, least popular. Philippine Centre for Investigative Journalism, August-September

Quimpo NG (2009) The Philippines: predatory regime, growing authoritarian features. Pacific Rev 22(3):335-353 
Ramirez R (2017) Philippines expects 2 M Chinese tourists this year. Philippine Star, 19 March. http://www.philstar.com/headlines/2017/03/19/1682570/ philippines-expects-2-m-chinese-tourists-year

Ranada P (2016) Duterte bringing home \$24B worth of deals from China. Rappler. https://www.rappler.com/business/149886-duterte-business-deals-contractschina-visit

Rappler (2013) PH wins investment grade from Moody's. 3 October. https://www. rappler.com/business/economy-watch/40469-philippines-investment-grademoodys

Rappler (2015a) Fiscal incentives rationalization to add P30 B in Ph annual revenue. 19 August. https://www.rappler.com/business/economy-watch/66693fiscal-incentives-rationalization-add-ph-revenue

Rappler (2015b) Lower income tax rates? Aquino "not convinced" it's a good idea. 14 September. https://www.rappler.com/business/governance/105837-aquinono-income-tax-cut

Remitio R (2016). Two more PPP projects expected to be finished before Aquino's term ends, February

Reuters (2013a) U.S. raises military assistance to the Philippines, July

Reuters (2013b) Philippine clamps down on illegal miners, gold smugglers, Reuters. http://www.reuters.com/article/philippines-miningidUSL4N0XA0Y720150413

Santos (2012) PH, Chinese naval vessels in Scarborought Shoal standoff, Inquirer, 11 April. http://globalnation.inquirer.net/32341/ph-chinese-naval-vessels-inscarborough-shoal-standoff

Schinabel C (2015) Aquino: PH Will be "first-world" within generation if reforms continued. Rappler, 27 June. https://www.rappler.com/business/economywatch/100688-sona-2015-aquino-first-world

Schraeder PJ, Hook SW, Taylor B (1998) Clarifying the foreign aid puzzle: A comparison of American, Japanese, French, and Swedish aid flows. World Polit 50(2):294-323

Schroeder P (1994) Historical reality vs. neo-realist theory. Int Secur 19(1):108-148

Senate Economic Planning Office (2008) Revisiting the cyber education project, May. Policy Brief. Senate of the Philippines

Shan H (2012) Timeline of major events of China-Philippine diplomacy (1975-present). 12 February. The China and Philippine Portal

Simeon L (2016) China lifts import bank on Philippine bananas. Philippine Inquirer, 7 October. http://www.philstar.com/business/2016/10/07/1630958/ china-lifts-import-ban-philippine-bananas

Simmons BA (2005) Rules over real estate: trade, territorial conflict, and international borders as institution. J Confl Resolut 49(6):823-848

Singh JTN and Camba AA (2016) Neoliberalism, resource governance and the everyday politics of protests in the Philippines. Everyday Polit Econ Southeast Asia 49-71

Slater D (2010) Ordering power: Contentious politics and authoritarian leviathans in Southeast Asia. Cambridge University Press

Social Weather Stations (2017) Second Quarter 2017 Social Weather Survey: Net satisfaction rating of the Duterte National Administration at "Very Good" + 64. https://www.sws.org.ph/swsmain/artcldisppage/?artcsyscode=ART-2017 0829131855

Storey I (2008) Conflict in the South China Sea: China's relations with Vietnam and the Philippines. The Asia-Pacific Journal, Japan Focus 6(4):1-8

Tilghman A (2016) The U.S. military is moving into these 5 bases in the Philippines. Military Times, 21 March. https://www.militarytimes.com/news/ your-military/2016/03/21/the-u-s-military-is-moving-into-these-5-bases-inthe-philippines/

Tilly C (1992) Coercion, capital, and European states, AD 990-1992. Blackwell, Oxford

Thies CG (2004) State building, interstate and intrastate rivalry: A study of postcolonial developing country extractive efforts, 1975-2000. Int Stud Q 48 (1):53-72

Thies CG (2005) War, rivalry, and state building in Latin America. Am J Pol Sci 49 (3):451-465

Thies CG (2007) The political economy of state building in Sub-Saharan Africa. J Polit 69(3):716-731
Torres-Tupas (2013) LGU power over small-scale mining, limited. Inquirer, 29 April. http://newsinfo.inquirer.net/399321/lgu-power-over-small-scalemining-limited-says-sc

UNCTAD (2015) World Investment Report 2015: Reforming international investment governance. United Nations Conferences on Trade and Development

Walt SM (1990) The origins of alliance. Cornell University Press

Walt SM (1998) International relations: one world, many theories. Foreign policy (110): 29-46

Wang MY (2002) The motivations behind China's government-initiated industrial investments overseas. Pacific Aff 75(2): 187-206

$\mathrm{Xu}$ YC (2016) Sinews of power: The politics of the state grid corporation of China. Oxford University Press

Zengerle P (2017) Exclusive: U.S. stopped Philippines rifle sale that senator opposed-source. Reuters, 31 October. https://www.reuters.com/article/usphilippines-usa-rifles/exclusive-u-s-stopped-philippines-rifle-sale-thatsenator-opposed-sources-idUSKBN12V2AM

\section{Data availability}

The interviews analyzed during this study are cited in this published article but the sources are kept anonymous to protect the interviewees. For investment data, (a) Chinese foreign direct investment (FDI) data from the Philippine Investment Promotion Agencies can be acquired from the Philippine government; (b) the Ministry of Commerce (MOFCOM) of the People's Republic of China annually releases yearly reports, which can be found or purchased online: https://www.purpleculture.net/statistical-bulletin-of-chinas-outwardforeign-direct-investment-2015-p-24624/?zenid=5hfnu03rit120aushs0oih9524; and (c) the American Enterprise Institute's Chinese Global Investment Tracker's (CGIT) dataset can be found here: http://www.aei.org/china-global-investment-tracker/. All other data used in the article are cited.

\section{Acknowledgements}

Funding for the fieldwork conducted in 2017 came from the Southeast Asia Research Group's Pre-Dissertation Fellowship (url: http://seareg.org/financial/). I am especially grateful to Shirley Lung for her thorough comments on the initial draft of the manuscript and the multiple interviewees of this project for the interviews. I also would like to thank Ho-fung Hung, Kenneth Cardenas, and Aaron Francis Chan for ongoing conversations on the themes explored in this article.

\section{Additional information}

Competing interests: The author declares no competing financial interests.

Reprints and permission information is available online at http://www.nature.com/ reprints

Publisher's note: Springer Nature remains neutral with regard to jurisdictional claims in published maps and institutional affiliations.

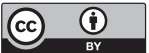

Open Access This article is licensed under a Creative Commons Attribution 4.0 International License, which permits use, sharing, adaptation, distribution and reproduction in any medium or format, as long as you give appropriate credit to the original author(s) and the source, provide a link to the Creative Commons license, and indicate if changes were made. The images or other third party material in this article are included in the article's Creative Commons license, unless indicated otherwise in a credit line to the material. If material is not included in the article's Creative Commons license and your intended use is not permitted by statutory regulation or exceeds the permitted use, you will need to obtain permission directly from the copyright holder. To view a copy of this license, visit http://creativecommons.org/ licenses/by/4.0/.

(C) The Author(s) 2017 